\title{
Mercado de Ações no Brasil: o Perfil de Risco da Expansão de 2004-2011
}

\author{
The Brazilian Stock Market: Risk Analysis \\ of the 2004-2011's Upsurge
}

\author{
Jennifer Hermann* \\ Norberto Montani Martins* *
}

\begin{abstract}
Resumo: $\mathrm{O}$ artigo analisa o perfil de risco do mercado de ações brasileiro (MAB) no período 2004-11, caracterizado pela forte expansão do mercado, após um longo período de retração. A análise constata uma evolução favorável dos indicadores de liquidez e, em menor escala, de volatilidade, e deterioração dos indicadores de concentração. Nestes, destacam-se, como principais fontes de risco: a elevada concentração da oferta em setores produtores de commodities e a elevada concentração da demanda em investidores estrangeiros. Conclui-se, assim, que o perfil de risco da expansão recente contribuiu de forma importante para o contágio do MAB pela crise externa e, portanto, para a desaceleração dos negócios a partir 2010.
\end{abstract}

Palavras-chave: Mercado de ações. Riscos. Contágio. Brasil.

Abstract: The current article aims at analyzing several risk indicators of the Brazilian Stock Market (BSM) in the period 2004-11, which is marked by a great spurt of BSM after many years of retraction and stagnation. Our analysis points out enhancements on liquidity and, in a lesser extent, volatility indicators, and the deterioration of indicators of market concentration. We emphasize that the main sources of risks are: high concentration of stock capitalization in commodity-related sectors and excessive concentration of demand in foreign investors. We conclude that these risks contributed significantly to spread contagion effects of the 2008-9' financial crisis in BSM and, therefore, to the slowdown in BSM's business since 2010.

Keywords: Stock markets. Risk. Contagion. Brazil.

JEL Classification: G10; G19.

\footnotetext{
* $\quad$ Professora do Instituto de Economia da Universidade Federal do Rio de Janeiro (UFRJ). E-mail: jenniferh@terra.com.br

** Mestrando do Instituto de Economia da Universidade Federal do Rio de Janeiro (UFRJ). Bolsista do Centro Internacional Celso Furtado de Políticas para o Desenvolvimento. E-mail: norberto.montani@gmail.com
} 


\section{1 lntrodução}

Após longo período de retração, que se estendeu de 1999 a 2003, teve início em 2004 uma fase de forte expansão das emissões primárias no mercado de ações brasileiro (MAB), em escala inédita no país. O mercado tornou-se mais instável a partir de fins de 2008, sob efeito da crise financeira internacional iniciada nos Estados Unidos da América (EUA), mas, até 2011, isto não chegou a provocar uma reversão da fase expansiva, caracterizando, aparentemente, apenas uma tendência de desaceleração. Assim, o ano de 2004 marca um ponto de inflexão na evolução recente do MAB.

A expansão continuada do mercado primário de ações é, em geral, um indicador positivo para a economia, sinalizando a vigência de expectativas favoráveis, tanto por parte das empresas emissoras - que, supostamente, buscam recursos para ampliar suas atividades - quanto dos adquirentes das ações. Além disso, a emissão de novas ações disponibiliza às empresas recursos de terceiros sem aumentar seu nível de endividamento, ou mesmo permitindo a redução deste, através de estratégias de reestruturação de passivos. Com isto, viabiliza-se o financiamento (funding) da atividade econômica com menor grau de exposição das empresas a riscos e, por extensão, de toda a economia à fragilidade financeira. Um mercado acionário em expansão, em suma, reflete e realimenta um ambiente econômico mais propício ao crescimento econômico sustentado.

A despeito de suas externalidades positivas, como qualquer segmento do mercado financeiro, o mercado de ações não é também isento de riscos. Os retornos com dividendos e ganhos de capital são condicionados, respectivamente, pelo desempenho financeiro das empresas emissoras (bem como por suas políticas de distribuição de lucros) e pelo comportamento do mercado secundário de ações - ambos, dependentes de um conjunto amplo de variáveis. Uma evolução desfavorável e imprevista dessas condições é sempre possível e, caso ocorra, pode se converter em efetivas perdas de recursos por investidores individuais e instituições financeiras.

A depender de suas proporções, essas perdas podem desencadear uma série de efeitos de contágio - sobre outros investidores e instituições, segmentos do mercado financeiro ou mesmo sobre o setor não financeiro - capazes de culminar numa crise sistêmica. A "Grande Depressão" dos anos 1930, deflagrada pela "quebra" das bolsas de valores de Londres e Nova York em 1929, é, certamente, a mais dramática ilustração desse risco. A crise econômica internacional ainda em curso, iniciada no mercado imobiliário norte-americano em 2007, teve também nos mercados nacionais de ações um importante canal de contágio para outros países. Além dessas experiências traumáticas, mais raras, a história econômica recente 
registra diversos outros episódios de crise financeira, de menor duração e impacto macroeconômico, iniciada no mercado de ações, ou por ele propagada. ${ }^{1}$

Tal como ocorre também em outros segmentos do mercado financeiro, as crises originadas no mercado acionário são sempre precedidas de períodos de forte expansão dos negócios. As crises se manifestam, basicamente, por dois movimentos, simultâneos ou encadeados:

a) brusca e significativa queda dos preços das ações no mercado secundário, caracterizando a chamada crise de deflação de ativos;

b) forte retração do volume de emissões primárias. A origem do problema é sempre a brusca queda da demanda por ações, refletindo um aumento, seletivo ou generalizado, do grau de aversão a risco dos investidores.

Assim, não é a expansão dos negócios em si que conduz, necessariamente, a tal desfecho, mas sim uma evolução desfavorável dos indicadores de risco de cada fase expansiva. Estes são também o principal condicionante do grau de contágio a que está sujeito o mercado, diante de um revés do mercado internacional, como o que se vivencia desde fins de 2008.

O contágio entre países é previsível e frequente na era da liberalização financeira - pós-anos 1980 - porque, entre outras condições, esta se caracteriza por ampla abertura dos diversos segmentos do mercado financeiro a fluxos externos de capital. A extensão do contágio, positivo ou negativo, em cada mercado nacional é condicionada pelo grau de abertura do segmento a investidores estrangeiros; pela efetiva atuação e peso relativo destes na dinâmica do mercado; e pelo grau de risco que lhe é atribuído pelos investidores de atuação global. Grosso modo, quanto maior o nível desses indicadores, maior a sensibilidade do mercado acionário ao ambiente externo.

Válida essa interpretação, o MAB reúne duas condições, em princípio, preocupantes:

$1 \quad$ Tendo por epicentro também o mercado acionário norte-americano, são exemplos de episódios de menor gravidade as crises da Bolsa de Nova York em 1987 e entre 2000-01 (a chamada crise das "ponto.com"), ambas com reflexos em outros países (KINDLEBERGER; ALIBER, 2005). No Brasil, registram-se vários períodos de dificuldades ou estagnação do mercado acionário, como a "quebra" da Bolsa do Rio de Janeiro em 1971, que manteve o mercado estagnado até fins dos anos 1980; a forte queda em fins dos anos 1990, como reflexo da crise asiática e dos ataques especulativos contra o Real no biênio 1997-98; e a longa fase de encolhimento das emissões primárias entre 1999-2003. No entanto, diante da estreiteza do MAB frente à economia doméstica e, mais ainda, frente ao mercado internacional de capitais, estes eventos não chegaram a gerar efeitos de contágio importantes. À medida que o mercado se expande, porém, amplia-se também o potencial de contágio de uma eventual crise. 
a) vivenciou um período de forte expansão a partir de 2004;

b) foi alvo de políticas de liberalização financeira desde o início dos anos 1990, sendo hoje amplamente aberto a fluxos internacionais de capital e, portanto, ao contágio do mercado internacional (PRATES, 1999; PRATES; FREITAS, 1999; HERMANN, 2005; UNICAMP; UFRJ, 2009; PAULA, 2011).

Partindo da hipótese, antes sugerida, de que o perfil de risco do mercado condiciona suas perspectivas no futuro próximo e atua como um "filtro" do contágio externo, este artigo propõe-se a analisar os indicadores de risco do MAB nos anos 2004-2011. Essa análise visa, basicamente, contribuir para uma melhor compreensão das condições - mais seguras ou mais frágeis - em que se deu o "renascimento" desse mercado no Brasil a partir de 2004. Além disso, pode orientar a avaliação de perspectivas do segmento - no sentido da expansão ou estagnação - no médio prazo.

Para tanto, o artigo está estruturado em quatro seções, além desta Introdução. A seção 2 apresenta um breve sumário estatístico da expansão do MAB no período em foco. A seção 3 esclarece aspectos metodológicos da análise. A seção 4 descreve o perfil de risco do mercado nos anos 2004-2011, a partir de três conjuntos de indicadores convencionalmente usados: concentração, liquidez e volatilidade. A conceituação e interpretação do papel desses indicadores na conformação do perfil de risco do mercado de ações, de modo geral, são também abordadas nesta seção. A seção 5 conclui o artigo, com uma síntese dos resultados obtidos e uma breve discussão sobre as possíveis implicações desse perfil de risco para as perspectivas do MAB no futuro próximo.

\section{Comportamento do MAB no Período 2004-2011: Breve Síntese}

\subsection{Principais Tendências no Mercado Primário}

Como já observado, os anos 2004-2011 caracterizam uma longa fase expansiva no $\mathrm{MAB}$, sem precedentes no segmento primário do mercado. Em médias anuais (a preços constantes de 2011), o período registra emissões da ordem de $\mathrm{R} \$$ 39,6 bilhões - $R \$ 316,8$ bilhões ao longo dos oito anos - quase 13 vezes superior à média dos anos 1999-2003 (Tabela 1). Esse aumento em relação aos anos de retração do mercado já impressiona, mas, certamente, é influenciado pela baixíssima base de comparação do período. Para que se tenha uma melhor noção da dimensão da retomada do MAB nos anos 2004-2011, é útil compará-los também ao período 1995-98, que representa a primeira fase expansiva do MAB após a estabilização de preços pelo Plano Real. Nesta comparação, o período 2004-2011 
mostra ainda níveis recordes de emissões primárias, equivalentes a 2,5 vezes a média anual do último período expansivo.

A média do período 2004-2011, porém, foi "inflada" por um evento atípico, ocorrido em 2010: a operação de capitalização da Petrobras, apoiada na emissão subsequente de novas ações (follow-on), no valor de $\mathrm{R} \$ 120,2$ bilhões correntes (ou $\mathrm{R} \$ 125,6$ bilhões, a preços de 2011). Essa única emissão representou 83\% do total emitido em 2010 e quase $40 \%$ do total de emissões ao longo de todo o período 2004-2011 (a preços de 2011). Além (e, provavelmente, pelo fato) de caracterizar um "ponto fora da curva" face à magnitude da emissão, esta não se deu como uma operação normal de mercado, tendo sido diretamente coordenada e amplamente regulamentada pelo governo federal (acionista controlador da empresa) no que tange a preços, compradores elegíveis etc ${ }^{2}$. Assim, para a compreensão das condições de evolução do mercado no período 2004-2011, convém depurar o dado de 2010 desta operação atípica.

Tabela 1- Mercado de Ações Brasileiro (MAB): indicadores selecionados Segmento primário

1995-2011 - R\$ milhões constantes de 2011 (Deflator: IGP-DI centrado)

\begin{tabular}{|c|c|c|c|c|c|}
\hline \multirow{4}{*}{ Período } & \multicolumn{5}{|c|}{ Emissões Primárias } \\
\hline & \multicolumn{4}{|c|}{ Ações } & \multirow{3}{*}{$\begin{array}{l}\text { Total de } \\
\text { MKB R\$ } \\
\text { Milhões }\end{array}$} \\
\hline & \multirow{2}{*}{$\begin{array}{c}\text { R\$ } \\
\text { Milhões }\end{array}$} & \multicolumn{3}{|c|}{$\%$ de } & \\
\hline & & Total MKB ${ }^{1 /}$ & FBCF & PIB & \\
\hline 2003 & 366 & 2,2 & 0,1 & 0,0 & 16,453 \\
\hline 2004 & 6,432 & 21,6 & 1,4 & 0,2 & 29,753 \\
\hline 2005 & 6,394 & 7,5 & 1,3 & 0,2 & 85,505 \\
\hline 2006 & 21,426 & 14,1 & 4,1 & 0,7 & 152,296 \\
\hline 2007 & 44,130 & 26,7 & 7,6 & 1,3 & 165,254 \\
\hline 2008 & 37,618 & 24,9 & 5,6 & 1,1 & 151,104 \\
\hline 2009 & 34,878 & 33,5 & 5,1 & 0,926 & 104,178 \\
\hline 2010 & 151,905 & 78,0 & 19,8 & 3,856 & 194,661 \\
\hline $2010^{*}$ & 26,260 & 38,0 & 3,4 & 0,7 & 69,016 \\
\hline \multicolumn{6}{|c|}{ Médias Anuais } \\
\hline $1995-98$ & 16.059 & 28,2 & 3,2 & 0,5 & 58.060 \\
\hline 1999-03 & 3.136 & 7,3 & 0,7 & 0,1 & 38.232 \\
\hline 2004-11 & 39.637 & 31,4 & 5,6 & 1,0 & 109.876 \\
\hline
\end{tabular}

2 Cabe destacar que, como consta no anúncio de encerramento de oferta pública, a oferta apresentou elevada endogenia: 77,0\% das ações ofertadas no follow-on foram adquiridas por entes ligados à companhia - como a União Federal, BNDES etc. 


\begin{tabular}{cccccc}
\hline $2004-11^{*}$ & 23.932 & 22,2 & 3,6 & 0,6 & 103.505 \\
$2004-05$ & 6.413 & 14,5 & 1,4 & 0,2 & 57.629 \\
$2006-09$ & 34.513 & 24,8 & 5,6 & 1,0 & 143.208 \\
$2010-11$ & 83.111 & 58,3 & 10,8 & 2,1 & 115.890 \\
$2010-11^{*}$ & 20.288 & 38,3 & 2,6 & 0,5 & 53.068 \\
\hline
\end{tabular}

Fonte: CVM, Ipeadata, BCB, BMEFFBovespa e IBGE.

Notas: ${ }^{1 /} \mathrm{MKB}=$ Mercado de Capitais Brasileiro, que inclui ações e títulos de dívida; * Exclui do total de 2010 a atípica emissão da Petrobras, no valor corrente de R\$120,2 bilhões (R\$ 125,6 bilhões, a preços de 2011).

Com esse procedimento, que balizará a análise do segmento primário do MAB nesta seção, a média anual de emissões do período 2004-2011 ainda se mantém recorde no país: $R \$ 23,9$ bilhões, ante $R \$ 16,1$ bilhões no ciclo expansivo de 1995-98. Na versão depurada, porém, ao contrário do que aponta o dado "cheio" (original), o ano de 2010 não marca o auge da fase expansiva recente, e sim o início de sua desaceleração, com emissões "de mercado" $25 \%$ inferiores ao nível de 2009. Essa tendência se acentua em 2011, com queda de $46 \%$ em relação ao valor ajustado de 2010 .

A análise ano a ano permite distinguir três fases distintas nos anos 2004-2011: a) o biênio 2004-05, que caracteriza um período de recuperação do mercado, após a longa retração iniciada em 1999; b) os anos 2006-09, que marcam o auge da tendência expansiva; c) o biênio 2010-11, de desaceleração, mas com um fluxo de negócios ainda elevado e superior ao da última fase de expansão. Como mostra a Tabela 1 (sempre em médias anuais, a preços constantes de 2011), as emissões primárias no MAB passam de $\mathrm{R} \$ 3,1$ bilhões ao ano nos anos 1999-2003 para $\mathrm{R} \$$ 6,4 bilhões no biênio 2004-05 (um crescimento de 106\%), e saltam para $R \$ 34,5$ bilhões nos anos 2006-09 (439\% de aumento), recuando para $R \$ 20,3$ bilhões no biênio 2010-11 (queda de 41\% em relação à média do período anterior).

Essas mesmas fases são observadas quando se medem as emissões primárias do $\mathrm{MAB}$ em relação à formação bruta de capital fixo $(\mathrm{FBCF})$ e ao Produto Interno Bruto (PIB). No primeiro caso, o índice dobra nos anos 200405 (para 1,4\%, ante 0,7\% entre 1999-2003), quadruplica no auge da fase expansiva (para 5,6\%) e recua no período 2010-11 (para 2,6\%), mantendo-se, porém, ainda superior à média da fase de recuperação. Os índices em relação ao PIB exibem comportamento semelhante. Aqui também, a dimensão da retomada do MAB a partir de 2004 fica mais clara quando se observa que este aumento nos índices relativos se deu em um período de retomada do crescimento do PIB e, em menor escala, da FBCF (Tabela 2). 


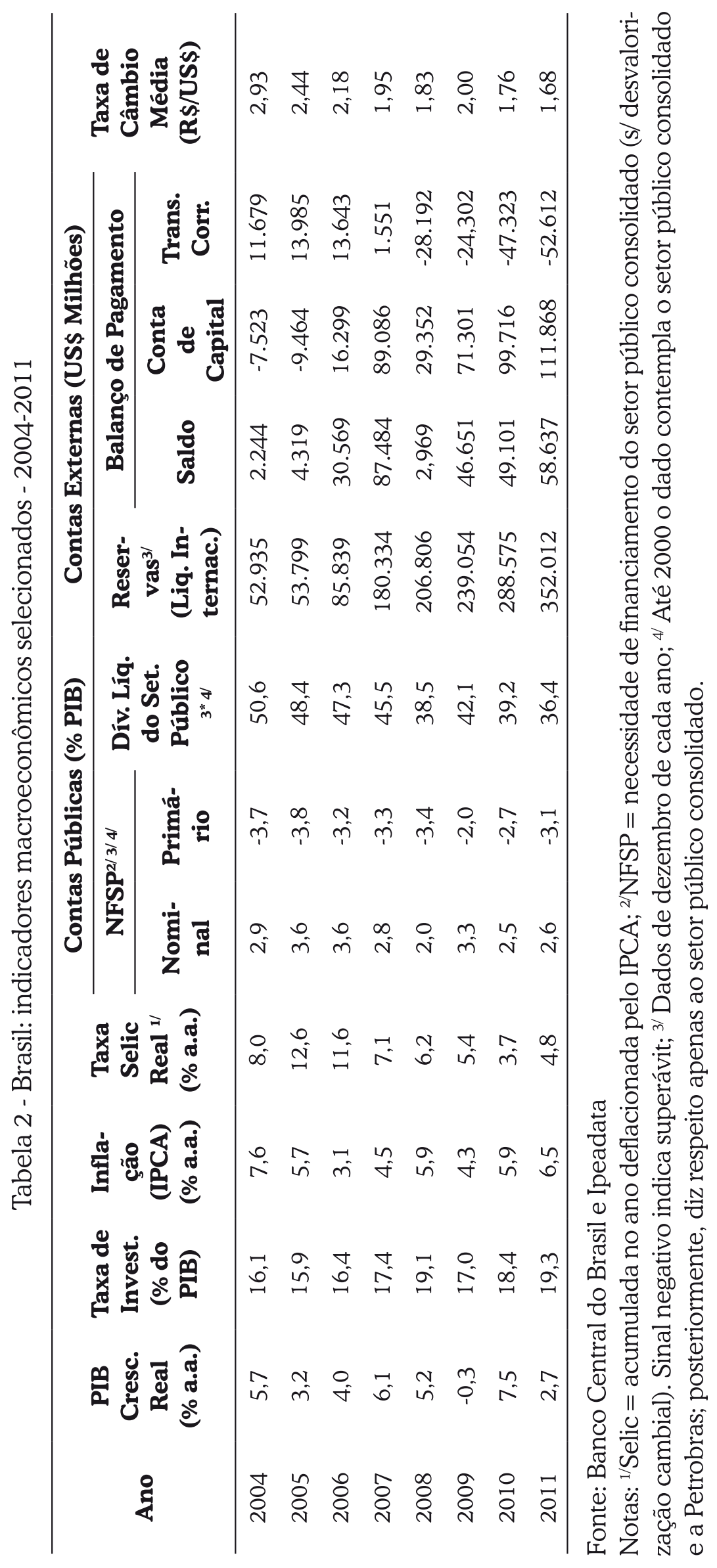

HERMANN, J.; MARTINS, N. M. Mercado de Ações no Brasil... 
Nos anos 2004-08, o comportamento do MAB refletiu uma rara combinação de condições macroeconômicas e financeiras favoráveis na economia internacional, entre elas: a) a vigência de juros baixos nos países industrializados; b) a retomada do crescimento econômico mundial, ancorada em ampla liquidez no mercado internacional; c) a expansão do mercado acionário nos países industrializados e, com maior força, nos emergentes.

Em conjunto, essas condições produziram uma espécie de "contágio positivo" da economia brasileira, contribuindo para a melhora das contas externas do país, apoiada em superávits comerciais, e para a retomada do crescimento econômico, acompanhada de estabilidade de preços, após três anos seguidos de estagnação (entre 2001 e 2003). Aliado aos avanços da regulamentação, bem como da auto-regulação financeira aplicada ao MAB desde o início da década - especialmente quanto às exigências de compromissos das empresas com seus acionistas - esse cenário justificou sensível melhora das expectativas de retorno das ações, não só por elevar os lucros esperados das empresas emissoras, mas também por reduzir os riscos deste tipo de aplicação no país. ${ }^{3}$

Analogamente, a reversão daquelas condições externas favoráveis em fins de 2008 contagiou negativamente a economia brasileira. O PIB chega a registrar leve retração em 2009 e a taxa de investimento, que vinha se recuperando desde 2006, sofre também retração neste ano.

No MAB, essa reversão só gera efeitos mais evidentes a partir de 2010, como já observado, quando se desconsidera a operação de capitalização da Petrobras. No entanto, já era sintomático o fato de a manutenção de níveis elevados de emissões em 2008 e 2009 dever-se, em grande parte, a uma única operação em cada ano: respectivamente, a da Cia. Vale do Rio Doce, no valor corrente de $\mathrm{R} \$ 19,4$ bilhões, que representou quase $60 \%$ das emissões de 2008 , e a do Banco Santander, no valor corrente de $\mathrm{R} \$ 14,1$ bilhões, equivalente a $47 \%$ do total emitido em 2009. A concretização dessas operações, em meio a um ambiente já desfavorável, se explica, basicamente, pelo próprio modus operandi do mercado de ações, e não por algum grau de "descolamento" do MAB em relação a tal ambiente. Quando se trata de grandes emissões, de empresas de grande porte, com atuação internacional - como é o caso das duas aqui mencionadas - a operação costuma envolver um longo prazo de planejamento e negociação, fazendo com que, às vezes, a efetiva emissão ocorra em um contexto distinto daquele que a motivou.

Assim, o biênio 2008-09, mais que simples extensão da fase expansiva iniciada em 2004, caracteriza um período de transição para uma fase de desaceleração,

3 Para uma análise mais detida sobre a influência dessas condições sobre o mercado de ações no Brasil, ver Unicamp e UFRJ (2009). Para uma abordagem mais sintética, ver Hermann (2010). 
cuja duração e intensidade é condicionada pela evolução da crise externa e pelo perfil de risco da expansão recente.

\subsection{Principais Tendências no Mercado Secundário}

No mercado secundário observam-se tendências, em geral, semelhantes às do segmento primário do MAB quando se considera todo o período 2004-2011, mas não os subperíodos aqui definidos. Os volumes negociados e os índices de capitalização absoluta (valor de mercado das empresas negociadas em bolsa) e relativa (valor de mercado em percentual do PIB) são recordes históricos no país no período 2004-2011 (Tabela 3), mas: a) a intensidade das mudanças no mercado secundário foi, em geral, menos impressionante que a observada no segmento primário; b) os anos 2006-2009 não concentram as maiores médias anuais de negócios e de capitalização absoluta, mas sim o biênio 2010-11.

Tabela 3 - Indicadores selecionados do mercado de ações brasileiro -

Segmento secundário

1995-2011 - R\$ milhões constantes de 2011 (Deflator: IGP-DI centrado)

\begin{tabular}{|c|c|c|c|c|c|c|c|}
\hline \multirow{3}{*}{ Período } & \multicolumn{3}{|c|}{ Valor Negociado } & \multicolumn{2}{|c|}{ Capitalização } & \multicolumn{2}{|c|}{ Ibovespa $^{3 /}$} \\
\hline & \multicolumn{2}{|c|}{ Ações (A) $)^{1 /}$} & \multirow{2}{*}{$\begin{array}{c}\text { Total do } \\
\text { MKB }^{2 /} \\
\text { R\$ } \\
\text { Milhões }\end{array}$} & \multirow[b]{2}{*}{$\begin{array}{c}\text { R\$ } \\
\text { Milhões }\end{array}$} & \multirow[b]{2}{*}{$\begin{array}{c}\text { \% do } \\
\text { PIB }\end{array}$} & \multirow[b]{2}{*}{ Pontos } & \multirow[b]{2}{*}{$\begin{array}{c}\Delta \text { Real \% } \\
\text { a.a. }\end{array}$} \\
\hline & $\begin{array}{c}\text { R\$ } \\
\text { Milhões }\end{array}$ & $\begin{array}{c}\text { A/Emiss. } \\
\text { Prim. }\end{array}$ & & & & & \\
\hline 2003 & 325.506 & 889,5 & 363.399 & 1.076 .684 & 39,8 & 22.236 & 84,5 \\
\hline 2004 & 432.489 & 67,2 & 452.536 & 1.286 .996 & 46,6 & 26.196 & 53 \\
\hline 2005 & 562.432 & 88,0 & 589.303 & 1.582 .435 & 52,6 & 33.455 & 25,9 \\
\hline 2006 & 810.280 & 37,8 & 830.174 & 2.090 .303 & 65,2 & 44.473 & 28,3 \\
\hline 2007 & 1.499 .783 & 34,0 & 1.533 .929 & 3.098 .285 & 93,1 & 63.886 & 32,8 \\
\hline 2008 & 1.584 .742 & 42,1 & 1.659 .198 & 1.584 .079 & 45,4 & 37.550 & $-45,9$ \\
\hline 2009 & 1.512 .250 & 43,4 & 1.613 .000 & 2.714 .743 & 72,1 & 68.588 & 84,4 \\
\hline 2010 & 1.674 .617 & 11,0 & 1.760 .723 & 2.684 .709 & 68,2 & 69.304 & $-9,2$ \\
\hline $2010^{*}$ & 1.674 .617 & 63,8 & 1.760 .723 & 2.684 .709 & 68,2 & 69.304 & $-9,2$ \\
\hline 2011 & 1.616 .420 & 112,9 & 1.679 .755 & 2.294 .410 & 55,4 & 55.754 & $-23,0$ \\
\hline \multicolumn{8}{|c|}{ Médias Anuais } \\
\hline $1995-98$ & 490.031 & 37,9 & 579.611 & 708.804 & 24,3 & 7.080 & 16,8 \\
\hline 1999-03 & 355.259 & 265,6 & 391.260 & 977.048 & 35,7 & 15.886 & 24,4 \\
\hline
\end{tabular}


(conclusão)

\begin{tabular}{cccccccc}
\hline $2004-11$ & 1.211 .627 & 54,6 & 1.264 .827 & 2.166 .995 & 62,3 & 49.901 & 12,3 \\
$2004-11^{*}$ & 1.211 .627 & 61,1 & 1.264 .827 & 2.166 .995 & 62,3 & 49.901 & 12,3 \\
$2004-05$ & 497.461 & 77,6 & 520.920 & 1.434 .715 & 49,6 & 29.826 & 15,6 \\
$2006-09$ & 1.351 .764 & 39,3 & 1.409 .075 & 2.371 .852 & 68,9 & 53.624 & 24,9 \\
$2010-11$ & 1.645 .518 & 62,0 & 1.720 .239 & 2.489 .559 & 61,8 & 62.529 & $-16,1$ \\
$2010-11^{*}$ & 1.645 .518 & 88,3 & 1.720 .239 & 2.489 .559 & 61,8 & 62.529 & $-16,1$ \\
\hline
\end{tabular}

Fonte: CVM, Speadata, BCB, BMFEBBovespa e IBGE.

Notas: ${ }^{1 /}$ A Bovespa passou a incluir as negociações referentes à Bolsa de Mercadorias e Futuros a partir de 2008; ${ }^{2 /}$ Inclui Certificados de Depósitos em Ações, Sistema Nacional de Debêntures e SOMA; ${ }^{3 /}$ Deflator para cálculo da variação real: IGP-DI centrado; * Para o cálculo da relação A/Emiss.Prim., exclui das emissões primárias de 2010 a atípica emissão da Petrobras, no valor corrente de $\mathrm{R} \$ 120,2$ bilhões ( $\mathrm{R} \$ 125,6$ bilhões, a preços de 2011).

Algum descompasso entre os dois segmentos do mercado de ações é previsível, especialmente nos momentos de reversão cíclica do mercado. Nas fases de fraco otimismo, ou mesmo de pessimismo (como entre 1999-2003 e a partir de 2009), a retração dos negócios no segmento primário tende a ser mais forte que no mercado secundário. Neste último, os volumes negociados são mantidos, ou mesmo "inflados", pela maior frequência das operações de revenda e, portanto, os volumes financeiros mostrarão retração menor que a do mercado primário (à exceção do caso onde haja uma queda de preços muito acentuada). Analogamente, na fase de expansão das emissões primárias o mercado secundário tende a mostrar crescimento menos acentuado, especialmente no início dela, quando as novas ações emitidas tendem a ser retidas por mais tempo pelos compradores, mais otimistas quanto às possibilidades de ganhos maiores no médio ou longo prazo.

O relativo descolamento entre os volumes negociados nos dois segmentos do MAB se traduz também em certo descolamento do Ibovespa - determinado no mercado secundário - em relação ao comportamento do mercado primário, bem como em relação aos indicadores macroeconômicos do país. Paradoxalmente, os anos 1999-2003, de forte retração do segmento primário do MAB e de instabilidade macroeconômica (baixo crescimento econômico, maior inflação e piores indicadores fiscais e externos), mostram um retorno real médio muito próximo ao dos anos 2006-09 (da ordem 25\%) e até superior ao da fase de recuperação (2004-05).

Tal comportamento se explica pelo caráter naturalmente especulativo dos negócios no mercado secundário, cujas transações ocorrem com maior frequência que no segmento primário, guiadas por objetivos de ganhos (ou contenção de perdas) de capital no curto prazo. Diante da constante possibilidade de (re) compra e (re)venda, essas operações acabam por refletir mais o "humor" e "expertise" do mercado a cada momento, que as reais condições de geração de lucros 
pelas empresas, cujas mudanças não são perceptíveis no curto prazo. Além disso, as variações do Ibovespa no agregado refletem também sua composição setorial: o grau de concentração dos negócios em setores específicos, a cada momento, pode, às vezes, gerar movimentos, aparentemente, pouco sintonizados com o ambiente geral do mercado e mesmo da economia. Por essas razões, para o mercado secundário, a análise ano a ano tende a ser mais esclarecedora que a análise das médias dos períodos, já que a dispersão, neste caso, tende a ser maior.

De todo modo, como os preços gerados no mercado secundário são uma referência para os preços de novas emissões e afetam permanentemente as possibilidades de ganhos de capital (com ações novas e antigas), as condições de operação deste acabam por se refletir, mais cedo ou mais tarde, no mercado primário. Assim, o descolamento entre as tendências observadas nos dois segmentos do MAB (assim como em qualquer outro mercado de ações) é mais aparente que real e se deve, em grande parte, à defasagem temporal entre os movimentos do mercado secundário e sua efetiva influência no mercado primário.

Embora não seja possível, pela simples observação, estabelecer uma relação direta e funcional entre as duas variáveis - já que a defasagem temporal entre elas não é regular - é possível identificar certo padrão de comportamento no período. Não por acaso, os anos de variações mais acentuadas do Ibovespa - positiva em 2003 e negativa em 2008 - foram seguidos de mudanças na mesma direção nos fluxos de negócios no mercado primário - forte expansão a partir de 2004 e desaceleração a partir de 2009. Analogamente, o período em que o Ibovespa mostrou seguidas variações positivas - entre 2003-07 - coincide com a fase de "expansão sustentável" das emissões primárias do MAB.

Os índices de capitalização absoluta, formados pela combinação do preço e do estoque de ações de cada empresa em mercado, a cada período, acabam por refletir também o caráter especulativo do mercado secundário de ações. Contudo, como as negociações secundárias não alteram o estoque de ações em mercado (que apenas "troca de mãos"), os índices de capitalização absoluta acompanham, essencialmente, os movimentos dos preços - do Ibovespa, no caso do MAB. Os índices de capitalização relativa têm seus movimentos amenizados pelas variações do PIB, que cresceu também no período 2004-11, mas, em geral, mostraram tendências semelhantes às dos índices absolutos.

Assim, os anos de continuado aumento do Ibovespa (2003-07), embalado pelo otimismo dos investidores - essencialmente dos estrangeiros, como se mostrará adiante - coincidem com os de aumento dos indicadores absolutos e relativos de capitalização do mercado. Da mesma forma, a volatilidade do Ibovespa nos primeiros anos da crise externa - com forte queda em 2008 e forte aumento em 2009 - seguida de nítida tendência de queda nos dois anos seguintes, gerou movimentos semelhantes nos índices de capitalização. Esses indicadores do mer- 
cado secundário confirmam a impressão anterior, de que a extensão da fase expansiva do mercado primário até 2009 refletiu mais uma espécie de movimento inercial, que algum tipo de "blindagem" do MAB frente aos efeitos da crise externa.

\section{Aspectos Metodológicos}

Ações são ativos sem prazo de vencimento, que oferecem possibilidade de retorno na forma de dividendos ou de ganhos de capital pela revenda do ativo no mercado secundário. Esses ativos, assim, envolvem dois tipos de risco: risco de rendimento e risco de mercado. O primeiro decorre da possibilidade de frustração das expectativas do investidor quanto aos lucros da empresa emissora e/ou quanto à sua política de distribuição de dividendos. O risco de mercado se traduz pela possibilidade de depreciação do ativo no mercado secundário, especialmente se esta vier a tornar seu preço de (re)venda inferior ao preço original da compra. Ainda que a venda não seja concretizada nestas condições - o que transformaria o risco em perda efetiva de capital - tal possibilidade representa um risco permanente de perda patrimonial, deprimindo o valor de mercado do portfólio do investidor.

Para um investidor individual (pessoa física ou jurídica, profissional ou não), a avaliação do grau de risco de um ativo ou portfólio é, normalmente, apoiada na análise de um conjunto de variáveis que, supostamente, condicionam o retorno do ativo, às quais se atribui diferentes cenários de comportamento com diferentes probabilidades de ocorrência. Para o mercado de ativos como um todo, ou para um segmento específico dele - como o mercado de ações - a avaliação do grau ou perfil de risco que lhe caracteriza envolve, basicamente, variáveis de natureza sistêmica - e não microeconômica - isto é, variáveis ou condições capazes de afetar o risco de todo o mercado financeiro ou mesmo de toda a economia. Considerando os dois tipos de risco antes mencionados para as ações, pode-se identificar como principais fontes de risco sistêmico no mercado acionário:

a) instabilidade macroeconômica, incluindo o comportamento dos preços em geral, do nível de atividade econômica e de indicadores fiscais e externos: além de dificultar a formulação de expectativas, um quadro de instabilidade tende a afetar desfavoravelmente os lucros das empresas emissoras e, por conseguinte, as possibilidades de distribuição de dividendos;

b) volatilidade dos preços das ações no mercado secundário: de forma análoga à instabilidade macroeconômica, esta dificulta as estimativas de retorno das ações, neste caso em relação aos ganhos de capital, elevando o risco de mercado;

c) baixa disponibilidade de liquidez (no sentido de recursos líquidos) no mercado acionário, ou mesmo no mercado monetário 
em geral: isto restringe a demanda por ações (ou por ativos em geral), compromete a possibilidade de novas emissões e de renegociações a preços favoráveis e reduz o grau de liquidez do mercado (no sentido de facilidade de revenda) e, possivelmente, os preços das ações já em mercado - em especial, daquelas efetivamente (re)negociadas - elevando o risco de mercado;

d) elevada concentração das operações primárias ou secundárias em poucas empresas e/ou setores da economia (do lado da oferta) ou em poucos investidores (do lado demanda): ao atrelar a dinâmica do mercado a poucos negócios de grande peso no conjunto do mercado, esta condição contribuiu para o aumento da volatilidade dos preços associada a cada movimento do mercado (seja ele de compra ou venda).

Nos anos 2004-2011, como já observado, a instabilidade macroeconômica não esteve presente como fator de risco para o MAB. Ao contrário, o período foi, em geral, marcado pela retomada do crescimento econômico, por relativa estabilidade de preços e pela melhora de indicadores fiscais e externos no Brasil (Tabela 2), contribuindo para o cenário benigno que pavimentou a expansão do $\mathrm{MAB}$ nesses anos. Além disso, o ambiente macroeconômico, como um fator de risco isolado, influencia mais diretamente o risco de rendimento. Seus efeitos sobre o risco de mercado são indiretamente captados pelas condições de volatilidade, liquidez e concentração do mercado.

O risco de rendimento, por sua vez, afeta, essencialmente, investidores mais conservadores, que demandam ações com a intenção de retê-las em seu portfólio por muito tempo, visando, prioritariamente, os ganhos com dividendos. Estes, porém, são, em geral, minoria nos mercados de ações, que, em razão da maior liquidez que lhe é característica, tende a atrair, predominantemente, investidores de perfil mais especulativo, que visam ganhos mais rápidos no mercado secundário. Assim, embora importantes para os investidores diretamente envolvidos, o risco de rendimento e seus condicionantes acabam por ter pouca influência no comportamento e no perfil de risco do mercado de ações em conjunto - foco de nossa análise.

Pelas razões apontadas, a análise do perfil de risco do MAB neste artigo concentrar-se-á nos condicionantes do risco de mercado e, portanto, nas três outras fontes de risco mencionadas, que o afetam mais diretamente. Estas serão avaliadas a partir de indicadores de concentração, liquidez e volatilidade convencionalmente utilizados para o mercado de ações, cujo foco são os movimentos do mercado secundário, onde se define o risco de mercado. A concentração do mercado pode manifestar-se ainda no segmento primário que, neste caso, será tam- 
bém considerado. A metodologia de cálculo, bem como a interpretação de cada indicador, são apresentadas em suas subseções específicas, a seguir.

Finalmente, quanto às fontes de dados, foram utilizadas apenas fontes primárias, de natureza institucional: a Comissão de Valores Mobiliários (CVM), instituição oficial reguladora do mercado de capitais no Brasil, para a maioria das informações relativas aos segmentos primário e secundário do MAB; e a Bolsa de Valores de São Paulo (Bovespa) e o Sistema Nacional de Debêntures (SND), instituições privadas que, entre outras atribuições, coordenam a autorregulação do mercado. Estas últimas foram usadas como fontes complementares para o segmento secundário do $\mathrm{MAB}$, basicamente, para dados não apurados ou não informados de forma agregada pela CVM. De um modo geral, os indicadores do perí-odo 2004-2011 foram comparados aos de períodos anteriores, mas para alguns deles, face à indisponibilidade de dados, isto não foi possível. Nestes casos, a análise apoiou-se apenas na evolução do indicador ao longo do período em foco.

\section{Perfil de Risco do Mercado de Ações Brasileiro no Período 2004-2011}

\subsection{Grau de Concentração}

\subsubsection{Interpretação dos indicadores}

O grau de concentração do MAB será analisado tanto do ponto de vista da oferta, quanto da demanda, considerando, nos dois casos, as operações primárias e secundárias separadamente. No segmento primário consideram-se os seguintes indicadores de concentração:

a) da oferta, por setor de atividade das empresas ofertantes e ao tipo de emissão (inicial, subsequente ou mista);

b) da demanda, quanto a grupos específicos de adquirentes das ações. Nos dois casos, utilizam-se as classificações da CVM.

No mercado secundário, tendo por referência as classificações da Bovespa, são analisados os seguintes indicadores:

a) distribuição relativa do valor de mercado (capitalização absoluta) das empresas com ações negociadas na Bovespa, por número e porte das empresas e por setor de atividade;

b) distribuição relativa dos volumes negociados (compras e vendas no mercado secundário) entre diferentes grupos de investidores.

Um elevado grau de concentração da oferta sinaliza, em geral, maior risco para os investidores. Ao atrelar o desempenho do mercado ao de um número 
reduzido de grandes operações, essa condição tende a afetar desfavoravelmente os graus de liquidez e de volatilidade de todo o mercado. Essa influência desfavorável se dá através de dois canais: por efeito estatístico, decorrente do elevado peso relativo de cada operação, e por efeito demonstração, já que, na posição de líderes do mercado, as poucas empresas emissoras de ações passam, indiretamente, a ditar os preços - servindo de benchmark - para novos potenciais ofertantes. Além disso, uma oferta concentrada torna o mercado altamente vulnerável ao contágio de eventuais reveses nos setores ou empresas dominantes. Quanto à demanda, a concentração em grandes e poucos investidores também exerce influência desfavorável sobre o grau de liquidez e de volatilidade dos preços. Quando poucos negociadores detém grande parcela das ações em mercado, seu grau de liquidez reduz-se sensivelmente. Além disso, o peso relativo de cada operação (de compra ou revenda) pode gerar brusca mudança nos preços, aumentando a volatilidade potencial do mercado.

\subsubsection{Perfil de concentração do segmento primário do $M A B$}

A Tabela 4 mostra a distribuição da oferta primária de ações entre os setores com maior peso individual no MAB, no período 2004-2011. O primeiro aspecto a observar é a elevada concentração setorial das emissões: os cinco principais setores considerados concentraram $76 \%$ das emissões do período, ou $60 \%$, quando se exclui a operação de capitalização da Petrobras em 2010. Comparado ao período anterior, de retração (1999-2003), nota-se que, nesta versão depurada, o perfil da oferta nos anos 2004-2011 não é uma característica específica desta fase de expansão, já que, naquele período, os mesmos setores representaram quase $58 \%$ das emissões.

Tabela 4 - Emissões primárias no MAB por setor de atividade da Cia. ofertante Distribuição \% no acumulado dos períodos - 1999-2011

\begin{tabular}{ccccccccc}
\hline & & \multicolumn{7}{c}{ Setores de Atividade } \\
\cline { 3 - 8 } Período & Total & Bancos & $\begin{array}{c}\text { Constr. } \\
\text { Civil }\end{array}$ & $\begin{array}{c}\text { Energ. } \\
\text { Elétrica }\end{array}$ & $\begin{array}{c}\text { Extr. } \\
\text { Mineral }\end{array}$ & $\begin{array}{c}\text { Petróleo } \\
\text { e Gás }\end{array}$ & $\begin{array}{c}\text { Sub- } \\
\text { Total }\end{array}$ & Outros \\
\hline $1999-03$ & 100,0 & 31,9 & 5,1 & 5,3 & 6,9 & 8,4 & 57,6 & 42,4 \\
$2004-11$ & 100,0 & 9,9 & 9,9 & 3,4 & 8,9 & 43,5 & 75,7 & 24,3 \\
$2004-11^{*}$ & 100,0 & 16,5 & 16,4 & 5,6 & 14,8 & 6,4 & 59,7 & 40,3 \\
$2004-05$ & 100,0 & - & 6,9 & 22,1 & 11,6 & 0,5 & 41,1 & 58,9 \\
$2006-09$ & 100,0 & 7,5 & 19,1 & 7,5 & 23,8 & 7,6 & 65,4 & 34,6 \\
$2010-11$ & 100,0 & 4,4 & 3,0 & 0,1 & 1,4 & 78,3 & 87,2 & 12,8 \\
$2010-11^{*}$ & 100,0 & 18,3 & 12,2 & 0,5 & 5,7 & 10,7 & 47,4 & 52,6 \\
\hline
\end{tabular}

Fonte: CVM. Nota: 'Inclui material de construção e decoração; *Exclui emissão da Petrobras em 2010. 
É evidente, porém, o aumento do grau de concentração no auge da fase expansiva (2006-09), liderada pelos setores de extração mineral e construção civil, e no biênio 2010-11, liderado pelo setor de petróleo e gás, quando se considera a operação da Petrobras. Excluída essa emissão, o grau de concentração nesses cinco setores no biênio 2010-11 perde quase vinte pontos percentuais em relação ao auge da expansão. Isto pode indicar o início de um processo de desconcentração da oferta, mas dois anos são insuficientes para definir uma nova tendência, especialmente quando se leva em conta ser este um período de relativo encolhimento do mercado.

A concentração das operações primárias em poucos setores, sobretudo em economias com estruturas produtivas diversificadas, como a brasileira, é uma característica de mercados de ações pouco desenvolvidos. Além de elevar o risco a que se expõem os investidores, tal concentração denota um mercado de difícil acesso para a grande maioria dos setores de atividade. Um indicador positivo quanto a este aspecto foi o significativo aumento do peso relativo das Ofertas Públicas Iniciais (initial public offering - IPO, na sigla em inglês, mais conhecida) no período 2004-2011 (Tabela 5), que denota uma ampliação do acesso das empresas ao $\mathrm{MAB}$ - embora concentrado nos mesmos setores. Do ponto de vista do risco de rendimento e de mercado, porém, esse salto das IPOs é preocupante, já que as novas empresas de capital aberto não possuem um histórico de preços, nem no mercado primário, nem no secundário, que possa balizar as estimativas de retorno e ganhos de capital de suas ações.

Quanto à composição da demanda, dois aspectos positivos podem ser observados (Tabela 6). O primeiro é seu baixo grau de "endogenia": no período 2004-2011, o peso relativo das aquisições de investidores ligados à companhia emissora manteve-se numa média inferior a 7\% do total, sendo inferior a 6\% na fase de maior expansão (2006-09). $\mathrm{O}$ segundo é o baixo percentual de ações recompradas pelas companhias emissoras no ato da emissão. Os dois indicadores demonstram elevado grau de absorção da oferta pelo mercado, confirmando o maior interesse dos investidores por este tipo de ativo.

Tabela 5 - Emissões totais de ações por tipo de oferta

Distribuição \% - Médias por período - 2000-2011

\begin{tabular}{ccccc}
\hline \multirow{2}{*}{ Periodo } & \multicolumn{4}{c}{ Tipo de Oferta (R\$ bi)- } \\
\cline { 2 - 5 } & IPO & Subseq. & Mista & Total \\
\hline $2000-03$ & 1,4 & 94,3 & 4,3 & 100,0 \\
$2004-11$ & 27,1 & 49,8 & 23,1 & 100,0 \\
$2004-11^{*}$ & 29,2 & 44,5 & 26,3 & 100,0 \\
$2004-05$ & 29,7 & 42,3 & 28,1 & 100,0 \\
$2006-09$ & 31,5 & 48,4 & 20,1 & 100,0 \\
$2010-11$ & 15,7 & 60,2 & 24,0 & 100,0 \\
$2010-11^{*}$ & 24,0 & 39,0 & 37,0 & 100,0 \\
\hline
\end{tabular}

Fonte: CVM. Nota: *Exclui emissão da Petrobras em 2010. 
Tabela 6 - Emissões primárias (e distribuições secundárias) no MAB

Distribuição \% por adquirentes - Médias por período - 2004-2011

\begin{tabular}{lcccc}
\hline \multirow{2}{*}{\multicolumn{1}{c}{ Adquirentes }} & \multicolumn{4}{c}{ Médias (\%) } \\
\cline { 2 - 5 } & $\mathbf{2 0 0 4 - 1 1}$ & $\mathbf{2 0 0 4 - 0 5}$ & $\mathbf{2 0 0 6 - 0 9}$ & $\mathbf{2 0 1 0 - 1 ~ 1}$ \\
\hline Pessoas Físicas & 7,1 & 9,0 & 6,3 & 6,9 \\
Fundos e Clubes de Investimento & 20,0 & 20,0 & 16,7 & 23,5 \\
Fundos de Previdência & 1,9 & 2,9 & 1,3 & 2,2 \\
Investiments Estrangeiros & 54,7 & 53,1 & 54,5 & 56,8 \\
Instituições Financeiras (IF) & 2,3 & 2,6 & 2,5 & 1,5 \\
$\quad$ IF Intermediárias ${ }^{1}$ & 0,5 & 0,0 & 0,6 & 0,9 \\
\multicolumn{1}{c}{ IF ligadas à Cia. ${ }^{2}$} & 0,1 & 0,0 & 0,1 & 0,2 \\
\multicolumn{1}{c}{ Demais IF } & 1,7 & 2,6 & 1,9 & 0,4 \\
Demais pessoas jurídicas & 7,6 & 1,3 & 12,0 & 5,0 \\
Outros & 8,3 & 8,7 & 8,4 & 7,5 \\
Subtotal & 101,9 & 100,7 & 101,7 & 103,5 \\
Ações Recompradas pela Cia. & $-1,9$ & $-0,7$ & $-1,7$ & $-3,5$ \\
Total (\%) & 100,0 & 100,0 & 100,0 & 100,0 \\
Total de Adquirentes ligados à Cia. & 6,8 & 8,6 & 5,8 & 6,9 \\
\hline
\end{tabular}

Fonte: CVM: Anúncios de Encerramento de Distribuição Pública de Ações.

Notas: Os Anúncios de Encerramento de Distribuição Pública de Ações não permitem separar apenas as emissões primárias, incluindo também as distribuições secundárias associadas à mesma emissão; 1- Refere-se às instituições financeiras participantes do consórcio de distribuição; 2- Inclui: instituições financeiras ligadas à Companhia, ao coordenador líder, aos coordenadores contratados e/ou corretoras consorciadas; 3- Inclui: Cias. de seguro; pessoas jurídicas não financeiras e pessoas físicas ligadas à Cia. e outros.

No que tange à distribuição da demanda entre diferentes tipos de investidores, porém, há também sinais preocupantes. De um lado, chama atenção a baixíssima participação - a menor, entre os investidores selecionados - dos fundos de previdência privada nas aquisições primárias no MAB: cerca de $2 \%$, em média, em todo o período 2004-2011, e pouco mais de 1\% no auge da expansão. A fraca atuação desses fundos não chega a ser, em si, um fator de risco, mas priva o mercado de melhores condições neste sentido. Face ao elevado volume de recursos que movimentam e ao perfil de longo prazo de suas aplicações, os fundos de previdência contribuem, simultaneamente, para ampliar a liquidez e reduzir a volatilidade do mercado. Assim, não por acaso, essas instituições costumam ser grandes demandantes de ações em mercados mais desenvolvidos.

No outro extremo, ressalta a elevada concentração das aquisições primárias do MAB nos investidores estrangeiros. Estes detêm a maior fatia do mercado ao longo de quase todo o período 2004-2011 (55\%, em média), sendo a única ex- 
ceção o ano de 2008, quando o MAB sofre os primeiros impactos da crise internacional. A concentração da demanda em um grupo específico de investidores é, por si só, um fator de risco para o mercado de ações, pelas razões já apontadas. A concentração em investidores estrangeiros é ainda mais preocupante, porque envolve também algum grau de risco cambial, não só para os participantes do mercado, mas também para o conjunto da economia.

\subsubsection{Perfil de concentração do segmento secundário do MAB}

A partir de 2004, como já observado, seguindo a tendência de expansão do mercado primário, registra-se forte aumento do valor de mercado (capitalização absoluta) das empresas com ações negociadas na Bovespa, particularmente acentuado até 2007. Em paralelo, elevou-se a concentração do valor de mercado por empresas, em todas as categorias analisadas (Gráfico 1). Esse aumento da concentração ocorre principalmente entre as dez maiores empresas - nas quais figuram Petrobras, Cia Vale do Rio Doce (CVRD), Itaú, Bradesco, Banco do Brasil, Ambev, dentre outras - que elevam sua participação relativa em 5,6 pontos percentuais entre o início e o fim do período (Tabela 7).

Gráfico 1- Concentração do valor de mercado das empresas no MAB Participação \% do grupo de empresas referido - 2001-2011 (anos selecionados)

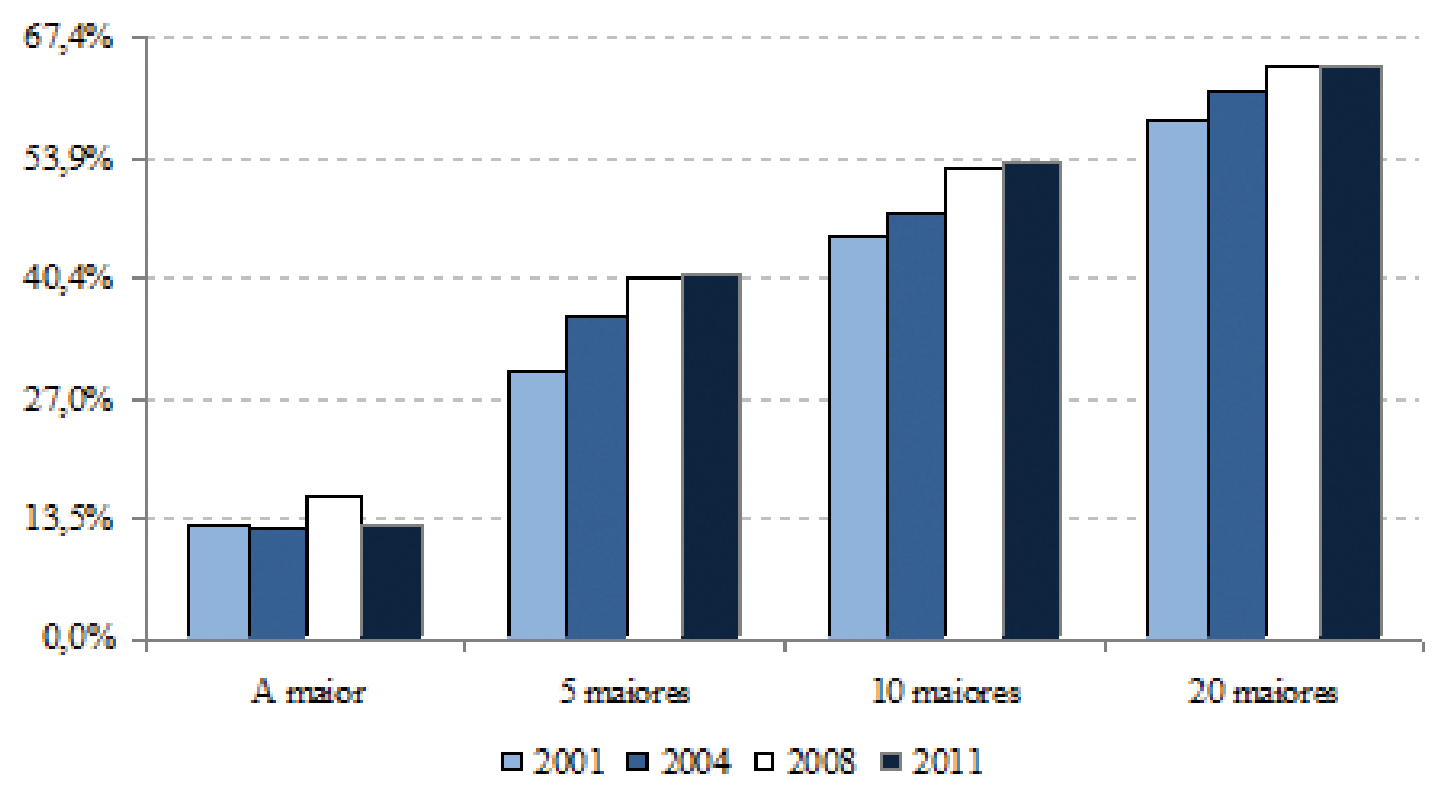

Fonte: Elaboração própria a partir de dados da BMEFBovespa.

À elevada concentração do mercado por empresas corresponde tendência semelhante quanto a seus setores de atividade: petróleo e gás, mineração, energia elétrica e bancos concentraram quase 60\% das operações da Bovespa em 2008 e cerca de $54 \%$ em 2011 , refletindo, em grande parte, a presença e o elevado 
peso das grandes empresas desses setores na Bolsa. O setor de telecomunicações é o único, entre os mais representativos do período anterior à expansão recente, que, ao longo desta, mostra tendência contínua de retração. Esse comportamento, porém, não se deve a condições específicas do $\mathrm{MAB}$, mas sim à reorganização do setor após o seu processo de privatização (em 1998), que além das típicas operações de aquisição de empresas públicas por companhias privadas, envolveu também o fechamento do capital de algumas delas. Além disso, contribuiu para essa tendência o desempenho ruim dos papéis relacionados, respondendo às incertezas relativas à reestruturação.

Entre os setores de maior peso relativo na formação do valor de mercado na Bovespa, três operam com bens que, em maior ou menor escala, são também negociados em bolsas internacionais - ou seja, operam com commodities. São eles: petróleo e gás, mineração e alimentos e bebidas, que, somados, representaram cerca de $40 \%$ da capitalização da Bovespa nos anos de expansão selecionados. Assim, o desempenho das ações desses setores é, em parte, condicionado pelo comportamento dos preços desses bens no mercado internacional, o que acaba por vincular o comportamento de todo o Ibovespa a estes preços. Como sugere o Gráfico 2, a correlação entre o Ibovespa e os índices de preços de algumas dessas commodities é elevada, sendo particularmente alta a correlação com os preços internacionais do petróleo e derivados, de maior peso na capitalização da Bovespa, entre os três setores considerados.

Tabela 7- Concentração do valor de mercado na Bovespa Participação \% dos principais setores e empresas - 2001-2011 (anos selecionados)

\begin{tabular}{ccccc}
\hline Empresa/Setor & $\mathbf{2 0 0 1}$ & $\mathbf{2 0 0 4}$ & $\mathbf{2 0 0 8}$ & $\mathbf{2 0 1 1}$ \\
\hline Petrobras & 12,7 & Empresas (\%) & \\
Vale & 4,6 & 12,4 & 16,3 & 12,7 \\
Eletrobrás & 4,0 & 9,2 & 10,2 & 9,1 \\
Ambev & 4,1 & 2,3 & 2,1 & 1,2 \\
Banco do Brasil & 1,6 & 6,2 & 4,1 & 8,2 \\
Banco Itaú & 4,6 & 2,9 & 2,7 & 3,0 \\
Itaúsa & 1,8 & 4,8 & 5,2 & 6,1 \\
Bradesco & 3,5 & 1,7 & 2,6 & 2,4 \\
Subtotal (\%) & 48,9 & 3,3 & 4,8 & 4,7 \\
Total do Mercado & 430,3 & 52,0 & 55,9 & 49,4 \\
(R\$ bilhões) & 904,9 & $1.375,3$ & $2.294,4$ \\
\hline & 13,2 & 12,8 & \\
\hline Petróleo e Gás & 10,2 & 17,5 & 15,2 \\
Mineração & 5,3 & 10,3 & 9,3 \\
\hline
\end{tabular}




\begin{tabular}{ccccc}
\hline $\begin{array}{c}\text { Alimentos e } \\
\text { Bebidas }\end{array}$ & 5,2 & 7,2 & 7,7 & 11,5 \\
Telecomunicações & 22,2 & 14,7 & 8,4 & 6,8 \\
Energia Elétrica & 13,6 & 9,6 & 10,0 & 9,2 \\
Bancos & 20,3 & 17,3 & 21,7 & 20,0 \\
Subtotal (\%) & 82,5 & 79,9 & 80,9 & 75,2 \\
Total do Mercado & 430,3 & 904,9 & $1.375,3$ & $2.294,4$ \\
(R\$ bilhões) & & & \\
\hline
\end{tabular}

Fonte: Elaboração própria a partir de dados da BMËFBovespa.

Gráfico 2- Evolução do Ibovespa x Índices de Commodities - 2004-2011

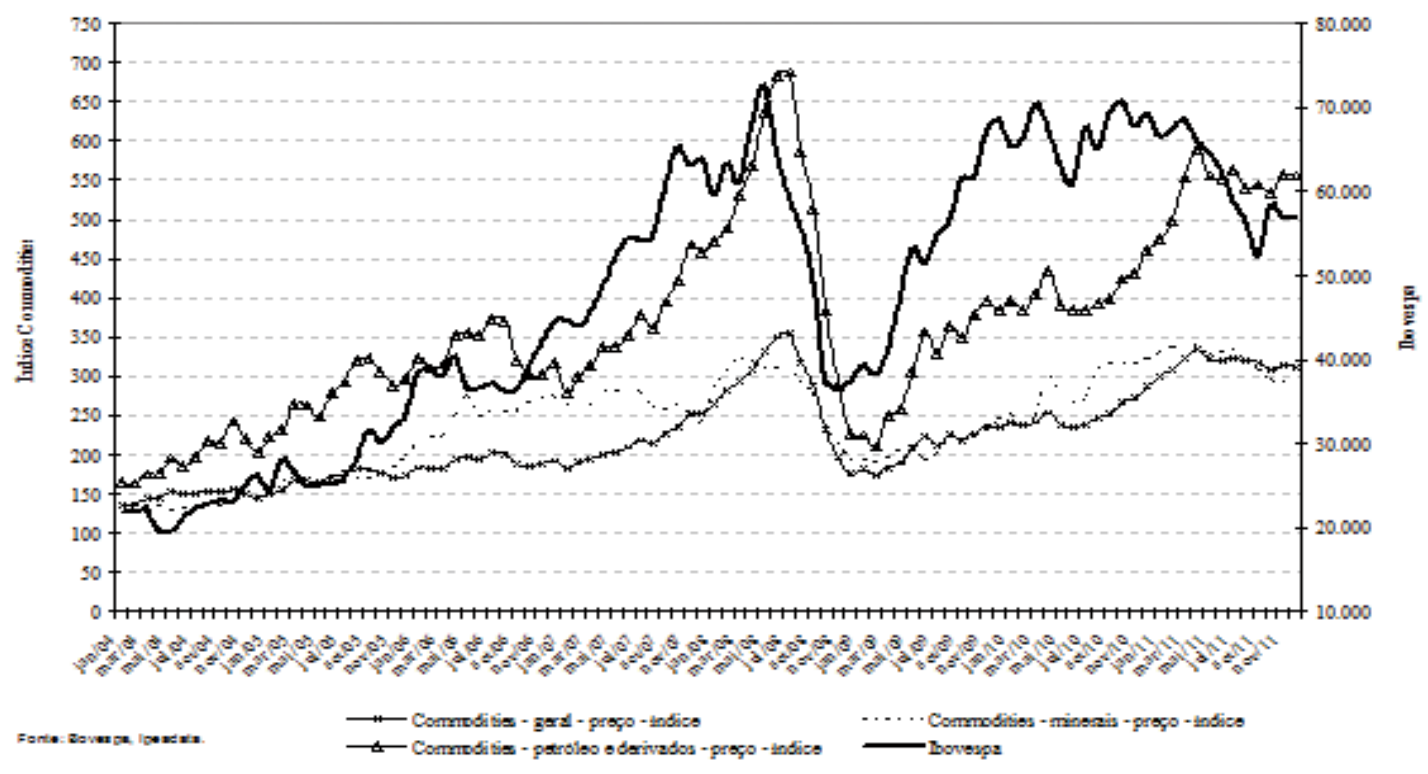

Fonte: BMEJFBovespa e Ipeadata.

A influência do mercado externo sobre o Ibovespa é maior quanto maior o grau de abertura do mercado secundário a investidores estrangeiros e quanto maior a efetiva atuação destes na bolsa. O grau de abertura do MAB a fluxos externos de capital é bastante elevado desde o início dos anos 1990 - mais especificamente, desde 1991, com a introdução do Anexo IV à Resolução 1.289 do CMN (Conselho Monetário Nacional), que reduziu imensamente os custos de transação e tributários das aquisições de ações no Brasil por parte de instituições estrangeiras. ${ }^{4}$

4 A Resolução 2.689 do CMN, de 2000, extinguiu a denominação Anexo IV, mas isto não significou qualquer redução no grau de abertura do MAB a investidores estrangeiros. Ao contrário, a Resolução 2.689 foi mais um instrumento de ampliação do grau de abertura do mercado de capitais brasileiro a estes investidores (HERMANN, 2005). 
Quanto à segunda condição, a distribuição dos volumes negociados na Bovespa entre diferentes tipos de investidores (Tabela 8) sugere que a atuação dos não residentes contribuiu também para estreitar os vínculos entre o Ibovespa e o mercado internacional de commodities. Assim como se observou na análise do mercado primário, estes investidores se destacam como os de maior peso relativo (embora menor que no segmento primário) nas negociações secundárias do MAB, sendo responsáveis por mais de 30\% das operações no período 2004-2011 e por 35\% no auge da fase expansiva (2006-09). Outra característica da demanda do segmento primário do $\mathrm{MAB}$ reproduzida no mercado secundário é a fraquíssima atuação dos fundos de previdência.

Tabela 8- Volume negociado no MAB - Distribuição \% por tipo de investidor 2001-2011 - Médias anuais

\begin{tabular}{lccccc}
\hline Tipos de Investidores & $\mathbf{2 0 0 1 - 0 3}$ & $\mathbf{2 0 0 4 - 1 1}$ & $\mathbf{2 0 0 4 - 0 5}$ & $\mathbf{2 0 0 6 - 0 9}$ & $\mathbf{2 0 1 0 - 1 1}$ \\
\hline Pessoas Físicas & 21,9 & 25,7 & 26,5 & 26,2 & 23,9 \\
$\quad$ Investidores Individuais & nd & 23,5 & 24,4 & 23,5 & 22,6 \\
$\quad$ Clubes de Investimento & nd & 2,2 & 2,1 & 2,7 & 1,4 \\
Institucionais & 21,4 & 29,0 & 27,8 & 27,5 & 33,3 \\
$\quad$ Companhias Seguradoras & 0,5 & 0,1 & 0,2 & 0,1 & 0,1 \\
$\quad$ Fundos de Pensão e de Seguridade & 3,7 & 1,8 & 3,1 & 1,5 & 1,2 \\
$\quad$ Fundos Mútuos e Clubes de Inv. & 17,1 & 27,0 & 24,4 & 25,8 & 32,1 \\
Investidores Estrangeiros & 25,1 & 33,0 & 30,1 & 34,9 & 32,2 \\
Empresas Públicas e Privadas & 3,3 & 2,3 & 2,7 & 2,3 & 2,0 \\
Instituições Financeiras & 28,0 & 9,8 & 12,8 & 9,0 & 8,5 \\
$\quad$ Banco Com. e Mút. Soc. Fin. & 13,1 & 6,5 & 8,2 & 6,6 & 4,4 \\
$\quad$ Bancos de Inv., DTVM e Corretoras & 14,9 & 3,4 & 4,6 & 2,4 & 4,1 \\
Outros & 0,2 & 0,2 & 0,3 & 0,1 & 0,1 \\
Total & 100,0 & 100,0 & 100,0 & 100,0 & 100,0 \\
\hline
\end{tabular}

Fonte: BMEFFBovespa. Inclui: operações nos mercaods à vista, a termo e de opções.

Finalmente, um aspecto positivo a se registrar nas operações secundárias do MAB no período de expansão recente é o aumento da participação das pessoas físicas e dos fundos e clubes de investimento, que, indiretamente, representam também pessoas físicas. Esses dois grupos de investidores domésticos representaram 53\% das negociações do período 2004-2011, ante 39\% no período 2000-03. Além de sinalizar uma tendência de "popularização" do mercado de ações no país, o aumento do peso relativo de investidores domésticos na Bovespa contribui, indiretamente, para conter o risco cambial antes mencionado. 


\subsection{Grau de Liquidez}

\subsubsection{Interpretação dos indicadores}

Um ativo é mais líquido quanto mais rapidamente puder ser convertido em moeda e, posteriormente, em qualquer outro. Como, em princípio, qualquer ativo pode ser revendido, todos têm algum grau de liquidez (KEYNES, 1985), mas este pode ser limitado pelo objetivo, que normalmente acompanha a decisão de venda por parte do investidor, de preservação do valor do ativo, ou mesmo de sua valorização. Como sintetiza Carvalho (1992, p. 85-86):

Liquidity is a bi-dimensional concept. It refers simultaneously to the duration of time required [...] to dispose of an asset and to the capacity this asset may have for conserving its value over time. Of course, anything can be disposed of very quickly if its possessor accepts a price low enough to find immediate buyers [...] Therefore, we may say that an asset is as liquid as the time requirede for its convertibility is short and the expected change in its value is small.

Uma condição estrutural para que um ativo tenha efetivamente alguma liquidez é a existência de um mercado de revenda - um mercado secundário - seja ele formal ou não. Uma condição importante para a formação desse mercado é o já mencionado grau de homogeneidade, ou padronização, dos ativos negociáveis: isto reduz o custo de transação envolvido na busca de agentes interessados em ativos com características específicas. ${ }^{5}$

Além desses condicionantes de natureza estrutural, a liquidez de um ativo, ou de um mercado de ativos, sofre inevitável influência de fatores conjunturais. Quanto a este aspecto, quanto mais favoráveis as expectativas em relação a determinado ativo, maior seu grau de liquidez no momento, porque este cenário contribui para ampliar sua demanda e, com ela seus preços de negociação nos mercados primário e secundário. Analogamente, para o conjunto do mercado de ações, um elevado grau de liquidez se manifesta pela presença simultânea de duas condições: a) elevado ou crescente volume negociado no mercado secundário, que indica elevada ou crescente demanda por ações; b) estabilidade ou crescimento do índice de preços das ações - isto indica que o maior volume de negócios não implicou ou exigiu redução dos preços das ações negociadas.

5 Davidson (1978, p. 87) destaca que os mercados secundários serão tanto mais profundos quanto: mais padronizados forem os ativos, maior a substitutibilidade entre eles, maior for o estoque de ativos em relação ao fluxo transacionado e maior a presença de market-makers (agentes que atuam como compradores ou vendedores residuais quando preciso). Neste sentido, o mercado de ações pode ser considerado, em geral, um mercado relativamente líquido (quando comparado ao mercado de títulos de dívida, por exemplo), já que os ativos nele transacionados apresentam um bom grau de padronização e substitutibilidade. 


\subsubsection{Liquidez do $M A B$}

A Tabela 3 e o Gráfico 3 mostram acentuado crescimento dos volumes negociados na Bovespa ao longo do período 2004-2008 e, praticamente, manutenção desses níveis a partir de 2009. Esse movimento foi acompanhado de firme tendência de valorização nominal e real do Ibovespa, interrompida apenas em 2008 - na verdade, no último trimestre do ano, quando tem início a crise financeira internacional. ${ }^{6} \mathrm{~A}$ julgar por esses indicadores, portanto, houve aumento do grau de liquidez no MAB ao longo do período 2004-2011, já que o forte aumento dos volumes negociados se conciliou com um cenário de aumento e posterior manutenção dos preços das ações mais negociadas (que compõem o Ibovespa).

Além da própria expansão do mercado, esse aumento de liquidez reflete também duas importantes mudanças estruturais no período recente. A primeira é resultante da criação pela Bovespa, a partir de 2000, de segmentos diferenciados de governança corporativa (GC). Estes envolvem uma série de exigências a serem cumpridas pelas empresas que, voluntariamente, decidam a eles aderir, tais como: a manutenção de um percentual mínimo (de 25\%) de ações "free float" que não se encontram nas mãos de controladores, investidores estratégicos (com mais de $5 \%$ do total) e/ou tesouraria; melhoria nas condições de divulgação de informações, quanto à frequência, volume, detalhamento e (redução do) grau de complexidade (visando sua compreensão por não especialistas); tratamento diferenciado a acionistas minoritários, buscando evitar que estes incorram em perdas decorrentes da dominação e possível manipulação do mercado por poucos grandes investidores, entre outras.

Os papéis listados nos níveis de GC diferenciada foram os grandes responsáveis pelo vigoroso crescimento do volume negociado no período 2004-2011 (Gráfico 4). A adesão de um número crescente de empresas a tais listagens teve como primeiro efeito o aumento da oferta de ações, via operações de distribuição secundária (venda por controladores e investidores estratégicos), num processo de adequação das empresas à exigência do percentual mínimo de ações na condição free float. Paralelamente, ao reduzir o grau de assimetria de informações do MAB, as maiores exigências em termos de GC contribuíram positivamente para ampliar a demanda por ações no MAB, viabilizando, assim, aquela expansão da oferta.

6 O evento emblemático que transformou a crise norte-americana, em curso nos EUA desde 2007, em uma crise sistêmica capaz de contagiar diversos países (inclusive o Brasil) foi o anúncio da falência de um grande e o tradicional banco de investimentos do país - o Lehman Brothers - em 15 de setembro de 2008 . 
Gráfico 3- Ibovespa x volume negociado no mercado secundário Pontos-base e R $\$$ bilhões

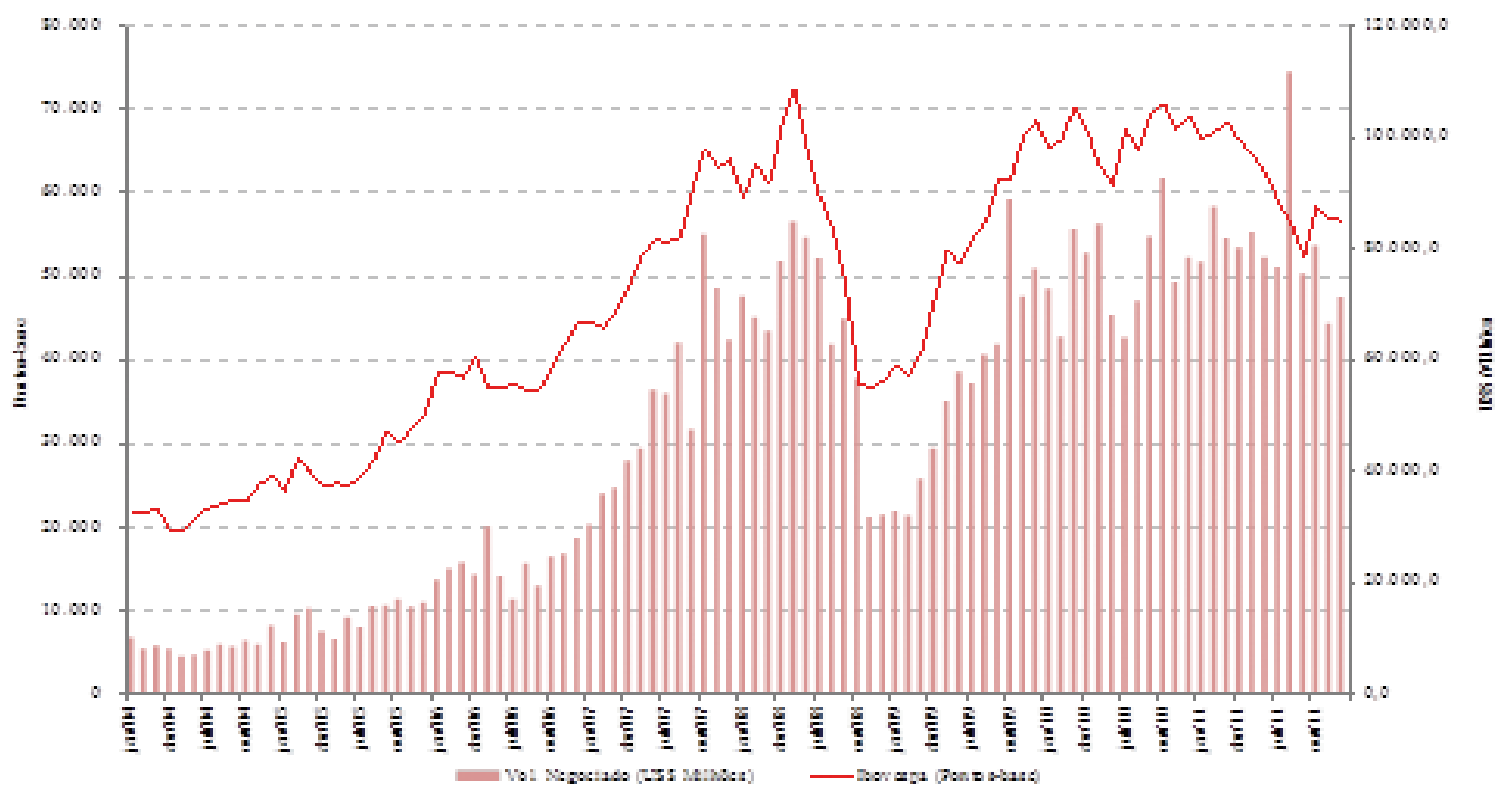

Fonte: Elaboração própria a partir de CVM e BMËFBovespa.

Gráfico 4 - Contribuição para o crescimento do total do volume negociado Pontos percentuais e \% a.a.

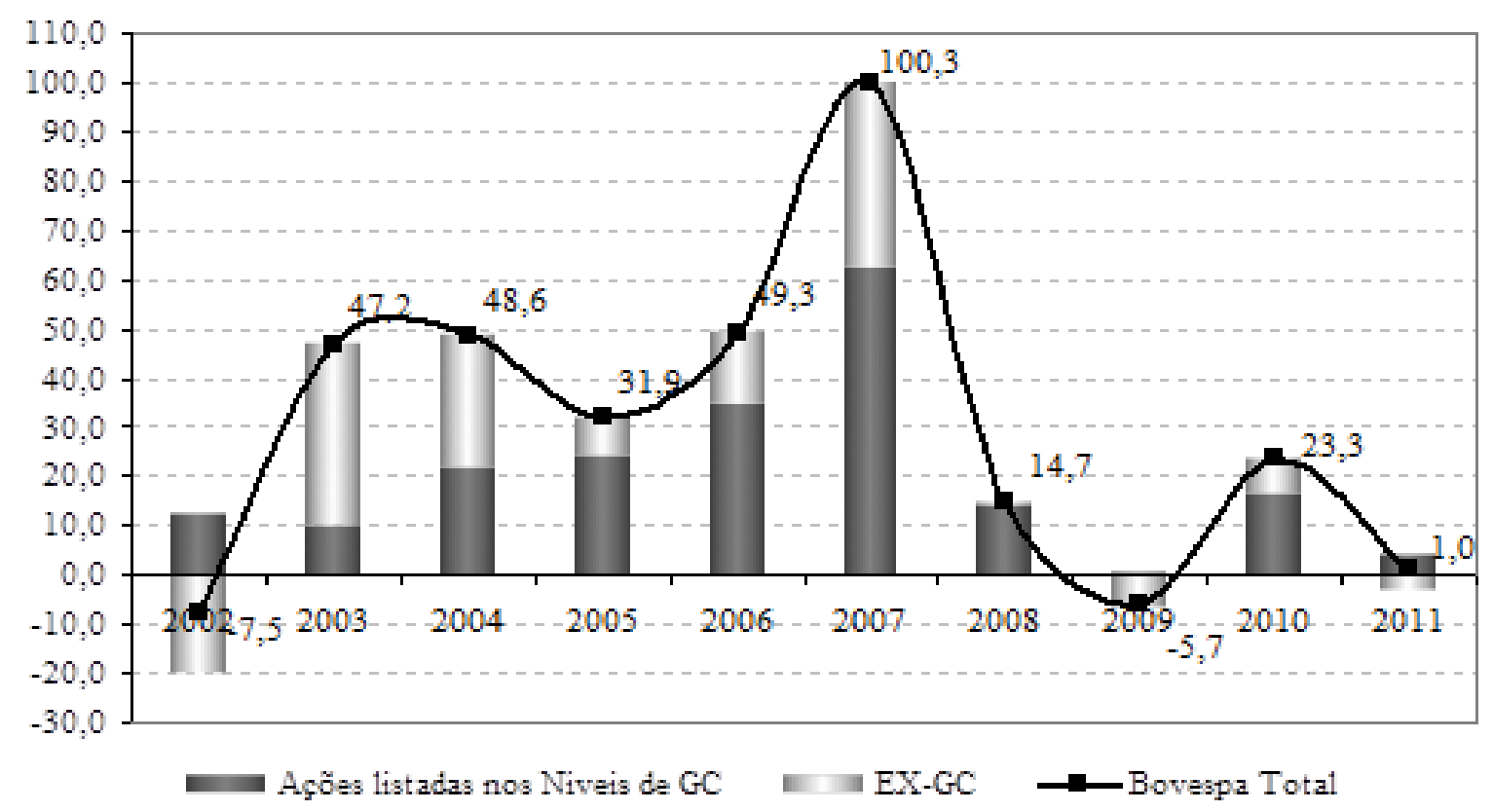

Fonte: Elaboração própria a partir de dados da BMËFBovespa.

A segunda mudança estrutural que exerceu influência positiva sobre a liquidez do MAB nos anos 2004-2011 foi a obtenção, pelo Brasil, do selo de investment 
grade junto às agências classificadoras de risco internacionais (inicialmente pela Standard $\mathcal{E}$ Poor's, seguida pela Fitch e pela Moody). Embora essa posição só tenha se concretizado a partir de abril de 2008 , as expectativas em torno de sua iminência ao longo de todo o ano de 2007 contribuíram para o aumento da liquidez do $\mathrm{MAB}$ desde então, especialmente no que tange à demanda externa. Além disso, grande parte dos investidores institucionais com atuação internacional só é autorizada, pela regulamentação financeira local, a operar com ações de países com tal classificação. A partir de abril de 2008, portanto, o MAB tornou-se um mercado elegível para esses investidores, ampliando-se, assim, a demanda potencial e a liquidez do mercado.

Um possível efeito indireto dessa nova condição é alguma redução no grau de volatilidade do mercado. Isto pode ocorrer porque, na ausência do investment grade, o mercado atrai, predominantemente, investidores menos sujeitos à regulamentação prudencial em seus países de origem e/ou mais propensos a riscos. Esses investidores visam, basicamente, ganhos de capital rápidos e imprimem um viés curto-prazista ao mercado, que tende a elevar seu grau de volatilidade e de vulnerabilidade a reveses no ambiente internacional. Não por acaso, nos mercados emergentes em geral, onde predominavam (e ainda predominam) países com classificação inferior à de investment grade, a expansão dos mercados de ativos que se seguiu às políticas de liberalização financeira foi acompanhada de aumento da volatilidade e da vulnerabilidade externa, culminando, na maioria deles, em crises cambiais (HERMANN, 2002). Assim, pode-se esperar que uma classificação superior na escala de risco do mercado internacional promova uma espécie de "salto de qualidade" nos investimentos estrangeiros, no sentido de alongar os prazos de retenção dos ativos, tornando-os menos especulativos.

Por essas razões e também pelo momento em que se deu - pouco antes do início da crise internacional - o investiment grade do Brasil, certamente, contribuiu de forma decisiva para a sustentação da demanda no MAB, especialmente a de origem externa, não só em 2008, mas também em 2009. Essa mudança estrutural e seus efeitos sobre a liquidez do mercado permitem, assim, compreender o prolongamento da fase expansiva do MAB até 2009, a despeito do ambiente de elevada incerteza gerado pela crise, e o adiamento da desaceleração para 2010, quando o investment grade já havia perdido grande parte da condição de novidade.

\subsection{Grau de Volatilidade}

\subsubsection{Interpretação dos indicadores}

A volatilidade dos preços ou de índices de preços de uma cesta de ativos designa um comportamento marcado por variações frequentes e de magnitude significativa em relação a seu padrão de comportamento em períodos recentes. 
Um indicador comumente usado para medir a volatilidade é o desvio padrão do referido índice ou preço ao longo de determinado período. No MAB, os indicadores de volatilidade usados pela Bovespa, cuja metodologia nos serve de referência neste artigo, são calculados pelo desvio padrão das variações diárias anualizadas dos índices em questão, ao longo de cada mês de negociação. ${ }^{7}$

Embora este procedimento permita um cálculo preciso da volatilidade, a interpretação desse resultado não é trivial, porque não existe um valor de referência que nos permita avaliar, de forma objetiva, se certo grau de volatilidade é satisfatório, alto ou baixo. ${ }^{8}$ Essa análise é, na prática, mais qualitativa que quantitativa, e baseia-se, essencialmente, na comparação do comportamento de um índice com outros afins, no mesmo período, e com ele mesmo, em períodos anteriores.

Assim avaliado, um ativo ou mercado com alta volatilidade emite sinais ambíguos para o s investidores. De um lado, oferece maior retorno potencial, na forma de ganhos de capital, em caso de forte aumento dos preços. De outro, sinaliza maior risco de perdas, diante de uma tendência baixista e, de um modo geral, eleva o risco de mercado a que se expõem os investidores, porque dificulta a formulação de estimativas dos preços futuros do ativo no mercado secundário e, portanto, das expectativas de ganhos de capital. No caso das ações, cuja única fonte de retorno possível no curto prazo é exatamente o ganho de capital, isto tende a atuar como um fator inibidor da demanda.

A baixa volatilidade, porém, não é necessariamente um fator de atração da demanda. Um quadro de maior estabilidade do preço do ativo, de fato, reduz a margem de erro das estimativas de preços futuros, caso se mantenham as condições que sustentam aquela estabilidade. Obviamente, porém, essa condição não é garantida. Além disso, preços estáveis sinalizam baixa probabilidade de ganhos (ou perdas) de capital, o que pode ser particularmente desanimador para os demandantes potenciais de ações.

Em suma, no mercado acionário, a alta volatilidade dos preços tende a inibir os investidores mais cautelosos, atraindo, porém, aqueles mais propensos a riscos. Por essa razão, mercados caracterizados por alta volatilidade não são, necessariamente, pouco dinâmicos; ao contrário, a possibilidade de elevados ganhos de capital pode, por vezes, sustentar fases expansivas, apoiadas em estratégias curto-

7 Formalmente, o procedimento para cálculo da volatilidade é o seguinte: a) calcula-se a variância de $\mathrm{u}$, dada por $\mathrm{s}^{2}(\mathrm{u})$, sendo $\mathrm{u}=\ln \left(\mathrm{P}_{\mathrm{t}} / \mathrm{P}_{\mathrm{t}-1}\right)$, onde $\mathrm{P}$ representa o preço da ação, ou o valor do índice em questão, e t representa o dia de validade de cada preço; b) em seguida, visando anualizar este resultado diário, multiplica-se $\mathrm{s}^{2}(\mathrm{u})$ pelo número de pregões no ano (252); c) por fim, para chegarse à volatilidade (v), medida pelo desvio padrão da variação anual, extrai-se a raiz quadrada deste resultado, ou seja: $\mathrm{v}=\sqrt{ }\left[\mathrm{s}^{2}(\mathrm{u}) .252\right]$ ou $\mathrm{v}=\mathrm{s} . \sqrt{ }(252)$. Ver, a respeito, Hull $(1998$, p. 252-255 e 264265).

8 Hull (1998, p. 252) afirma que "Os valores típicos da volatilidade de uma ação estão no intervalo de 0,2 a 0,4 ao ano", ou seja, entre $20 \%$ e $40 \%$. Isto, porém, é uma constatação meramente estatística - fruto da observação do histórico de volatilidade das ações no mercado norte-americano - e não um juízo de valor. 
prazistas, que conferem ao mercado um perfil mais especulativo. Esse quadro, porém, desfavorece a expansão sustentada de qualquer mercado, mas especialmente a do mercado acionário, dado o elevado peso dos ganhos de capital na formação do retorno esperado das ações.

Outro aspecto importante para subsidiar a interpretação de um indicador de volatilidade refere-se às possíveis causas do resultado. Grandes variações de preço derivam de grandes movimentos (fluxos) de compra ou venda, proporcionalmente ao tamanho prévio do mercado. Há, em princípio, três fatores a considerar, não mutuamente excludentes, como possíveis causas de um perfil de alta volatilidade (ou de baixa, na ausência delas):

a) um quadro de ampla convergência de expectativas no mercado, que leve grande parte dos investidores a optar, simultaneamente, pela compra ou pela venda de determinado(s) ativo(s), gerando grande pressão altista ou baixista sobre os preços;

b) um mercado altamente concentrado em poucos grandes investidores, de modo que qualquer movimento de um deles seja suficiente para gerar um impacto proporcionalmente grande sobre a demanda (no caso de compra) ou a oferta (no caso de venda) do mercado em questão, pressionando também os preços;

c) um quadro de baixa liquidez de grande parte do(s) ativo(s) negociado(s) no período: diante de um cenário de convergência de expectativas e/ou de concentração do mercado, os ativos de menor liquidez tendem a ser os responsáveis pela maior volatilidade dos preços, já que, por definição, os ativos mais líquidos não exigem grandes variações de preço para induzir o mercado à compra ou à venda.

\subsubsection{Volatilidade de preços no $M A B$}

Os indicadores de concentração e liquidez do $\mathrm{MAB}$, analisados anteriormente, geram efeitos ambíguos sobre a volatilidade: o aumento da concentração atua no sentido de ampliar e o aumento da liquidez no sentido de reduzir a volatilidade do Ibovespa. Nos anos 2004-07, apesar do elevado grau de concentração do MAB, a predominância de um cenário benigno no mercado internacional, bem como na economia brasileira, sustentou a alta liquidez do mercado, a ponto de manter relativa estabilidade do índice de volatilidade (em torno de 25\% - Gráfico 5).

Em 2008, o elevado grau de concentração da demanda, especialmente em investidores estrangeiros, aliado a um quadro de convergência de expectativas baixistas no mercado internacional, explica o salto da volatilidade do Ibovespa, que registra $45,8 \%$ na média do ano, tendo atingido o pico de 106,8\% em outubro. 
Embora pequenos em relação a seus mercados de origem - basicamente, mercados de capitais de países mais desenvolvidos - os investimentos estrangeiros têm peso significativo nos mercados emergentes - e no MAB, em particular - tornandose, por isto, um importante condicionante dos índices de concentração, liquidez e volatilidade desses mercados.

Esse movimento, provavelmente, teria sido ainda mais acentuado se o país não tivesse, recentemente, conquistado a classificação de investment grade no mercado internacional - que, como notado, tende a reduzir o grau de volatilidade do mercado. Nesse momento, porém, a elevada concentração do MAB em torno dos investidores estrangeiros às vésperas da crise externa revela seus efeitos perversos: mesmo o upgrade em sua classificação de risco, não foi suficiente para impedir a "fuga" de grande parte dos investidores estrangeiros em 2008. Além de reduzir drasticamente sua participação no segmento primário do MAB (para $28 \%$, ante $71 \%$ em 2007 - Tabela 6), esta comandou a tendência de queda do Ibovespa em 2008 (de $46 \%$ em termos reais - Tabela 3), bem como o aumento de sua volatilidade. Em 2009 esse indicador se reduziu, mas ainda se manteve acima da média “confortável" do período 2004-07. Esta só foi retomada no MAB a partir de 2010.

Gráfico 5 - Volatilidade do Ibovespa x Fluxo de Capital Estrangeiro em Ações Volatilidade mensal anualizada do Ibovespa (\%) e ingresso líquido de investimento estrangeiro em carteira em ações negociadas no país (US\$ milhões)

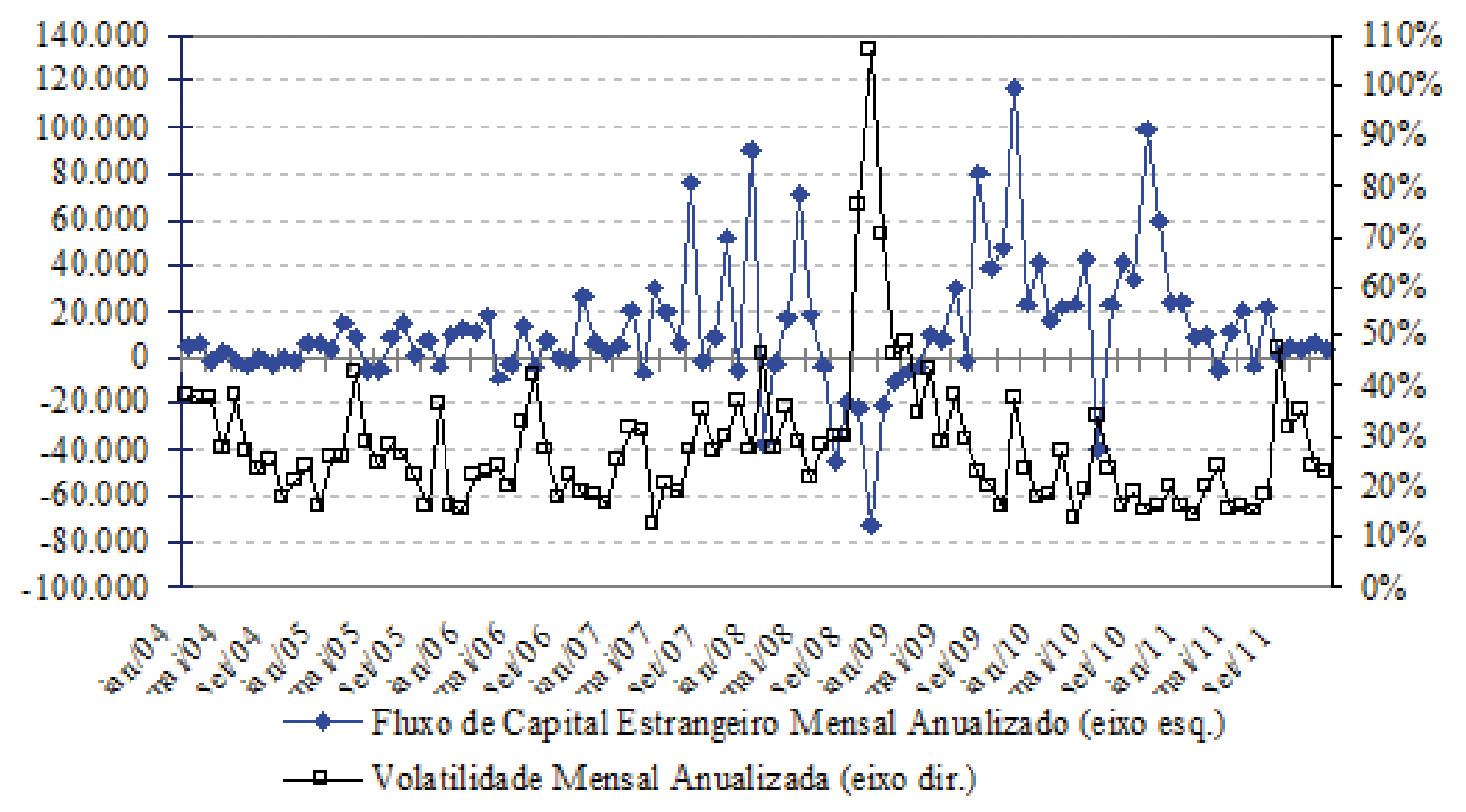

Fonte: Elaboração própria a partir de dados da BMËFBovespa e BCB.

Como antes observado, esse movimento de "fuga" não é claramente captado no indicador de volume negociado no mercado secundário, uma vez que este contabiliza as compras ou vendas em módulo. Assim, o movimento maciço 
de vendas por parte de investidores estrangeiros em 2008 resultou, inclusive, em pequeno aumento do volume negociado na Bovespa (Tabela 3), bem como da participação destes investidores na Bolsa (Tabela 6).

Gráfico 6 - Volatilidade do Ibovespa x Fluxo de Capital Estrangeiro em Ações em 12 meses

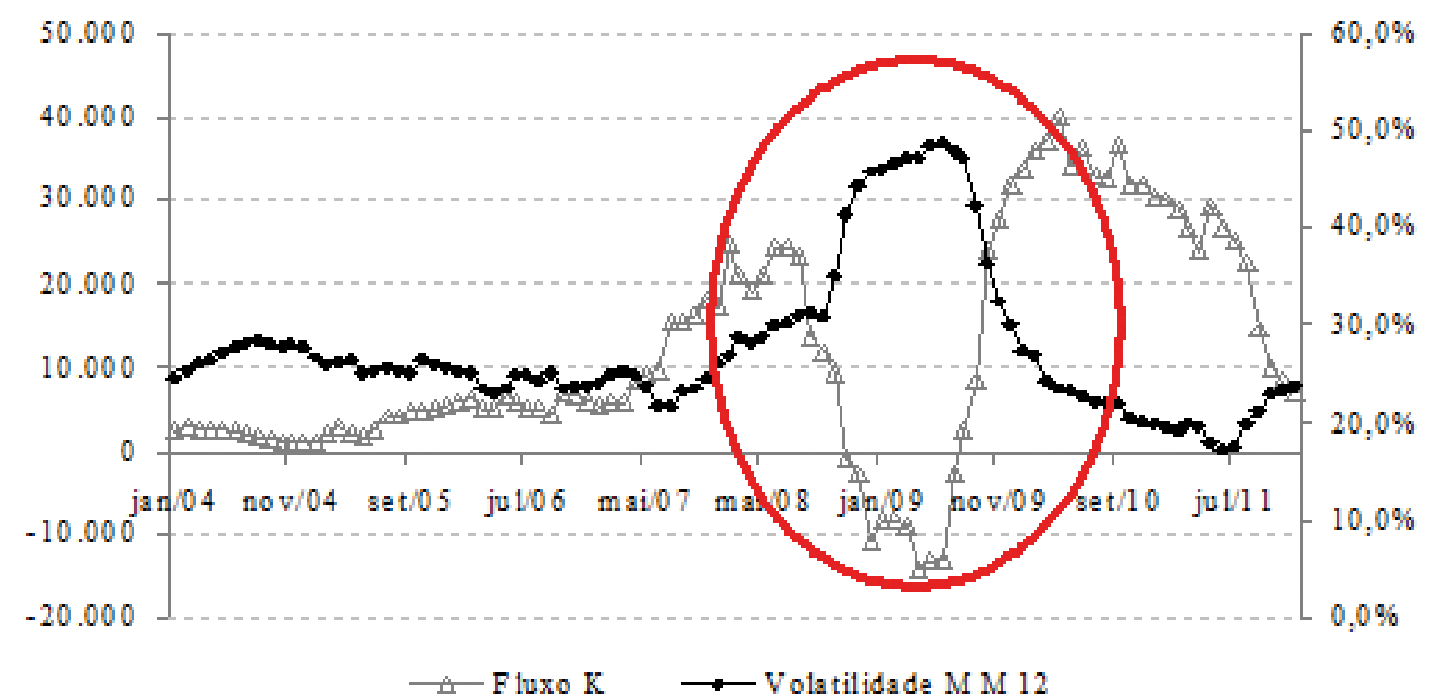

Fonte: Elaboração própria a partir de dados da BMËFBovespa e BCB.

Nota: Média Móvel em 12 meses da volatilidade mensal anualizada do Ibovespa (\%) e ingresso líquido de investimento estrangeiro em carteira em ações negociadas no país, acumulado nos últimos 12 meses (US\$ milhões).

Face à elevada concentração do MAB em torno dos investidores estrangeiros, o comportamento da volatilidade do Ibovespa ao longo de todo o período 20042011 demonstra clara correlação negativa com os fluxos de capital para o mercado acionário (Gráfico 6): os períodos em que estes mostram tendência crescente coincidem com os de menor volatilidade, enquanto os períodos em que este fluxo decai ou se mostra mais volátil correspondem aos de aumento da volatilidade - a área sombreada destaca o período mais severo da crise.

\section{Considerações Finais}

Este artigo analisou o perfil de risco do MAB nos anos 2004-11, que marcam uma fase de forte expansão deste mercado, sem precedentes no país, especialmente em seu segmento primário. A análise baseou-se em três conjuntos de indicadores: 
a) índices de concentração da oferta e da demanda nos segmentos primário e secundário do MAB;

b) índices de liquidez das ações;

c) índices de volatilidade dos preços das ações - os dois últimos, avaliados com base nas operações do mercado secundário.

A partir desses indicadores, constatou-se:

a) uma evolução favorável do grau de liquidez do MAB, que mostra nítida tendência de aumento ao longo de todo o período;

b) relativa estabilidade do grau de volatilidade do mercado, interrompida apenas no biênio 2008-09, como era de se esperar, por conta do ambiente de maior incerteza gerado pelo início da crise financeira internacional, ainda em curso;

c) deterioração dos indicadores de concentração, tanto do lado da oferta, quanto da demanda do MAB: quanto a este aspecto, destaca-se a elevada concentração das emissões primárias em poucos setores; o elevado peso relativo de setores ligados a commodities no comportamento do Ibovespa; e o elevado peso relativo dos investidores estrangeiros nos fluxos de negócios nos segmentos primário e secundário do MAB.

Essa última condição, especialmente no que tange à importância relativa dos investidores estrangeiros, é, certamente, o maior fator de risco da fase de expansão recente. As implicações desse perfil de concentração dos negócios para as condições de risco do MAB são previsíveis: eleva-se o grau incerteza quanto ao comportamento do mercado; sua vulnerabilidade a reveses do ambiente externo; o grau de volatilidade dos preços das ações e, portanto, o risco de mercado; e, indiretamente, eleva-se o risco cambial a que se expõe toda a economia.

Os fluxos internacionais de capitais, como se sabe, são condicionados, basicamente, pelo nível da liquidez internacional e pelas estratégias dos investidores globais. Estes são fatores de natureza conjuntural, potencialmente instáveis e, o que é mais importante, de difícil (às vezes, nenhum) controle por parte dos investidores, reguladores e gestores de política econômica do país receptor de capital. Por essa razão, a elevada participação de investidores estrangeiros no $\mathrm{MAB}$, embora traga a vantagem de ampliar sua liquidez, representa uma fonte permanente de incerteza quanto à dinâmica do mercado, em termos de volumes negociados e preços.

A incerteza, de um modo geral, atua no sentido de elevar os riscos de rendimento e de mercado atribuídos à aquisição de novas ações, inibindo, periodicamente, a expansão do segmento primário do mercado, que assume, assim, uma dinâmica do tipo stop and go. Além disso, se tal mercado tiver também um peso 
significativo na economia local - seja em relação à estrutura de financiamento das empresas e/ou ao sistema financeiro nacional - seus riscos se estendem a toda a economia, na forma de vulnerabilidade externa e, portanto, de risco cambial.

Não resta dúvida de que o "efeito-liquidez" da elevada demanda externa esteve na raiz do movimento de forte expansão do MAB iniciado em 2004. Por outro lado, no segmento primário, parece confirmar-se também uma trajetória do tipo stop and go, pelo menos desde 1995 (Tabela 1). Embora não se possa atribuir tal tendência, integralmente, ao elevado peso dos investidores estrangeiros, é inegável a contribuição desta condição para a formação desse quadro. Não é por acaso que as fases recentes de expansão (1995-98 e 2004-09) e desaceleração (1999-03 e 2010-2011) do MAB, embora menos acentuadas, coincidiram, com pequenas defasagens temporais, com tendências semelhantes no mercado internacional.

Quanto ao risco cambial que tal perfil de concentração da demanda pode implicar, paradoxalmente, a estreiteza relativa do segmento primário do MAB acaba sendo uma vantagem. Como mostrou a Tabela 1, no auge da expansão recente (2006-09), o fluxo de emissões primárias no MAB representou pouco mais de 5,5\% da FBCF do país; apenas 1\% do PIB (quando o crédito bancário representava cerca de 35\%); e 25\% de todo o mercado de capitais. Essa posição reduz a capacidade de contágio do MAB para o resto da economia brasileira, limitando o risco cambial associado a movimentos de fuga de capital do segmento primário do mercado.

O mesmo não se pode dizer, porém, em relação ao mercado secundário. Nesse caso, o risco cambial é, certamente, muito maior que o envolvido num eventual movimento de fuga de capital do segmento primário do MAB. Embora o peso relativo dos investidores estrangeiros seja bem menor no mercado secundário - de $33 \%$, em média, ante 55\% no segmento primário no período 2004-11 (Tabelas $8 \mathrm{e}$ 6 , respectivamente) - o volume negociado a cada período é muito maior - cerca de 54 vezes a média anual das emissões primárias no mesmo período (Tabela 3).

Nessas condições, um movimento de fuga de capital no mercado secundário pode representar uma perda significativa de divisas, com capacidade de atingir sensivelmente o mercado cambial do país. Isto ocorreu, por exemplo, nos ataques especulativos de 1997-98 contra o real, que antecederam a crise cambial de 1999, bem como, em menor escala, ao longo de todo o período 1999-2003. Embora o MAB não tenha sido o "pivô" das dificuldades cambiais do Brasil nesse período, é inegável que o elevado peso relativo dos investidores estrangeiros na Bovespa contribuiu de forma importante para a significativa queda dos volumes negociados (Tabela 3) e esta para o quadro de escassez de divisas que marcou o período.

Além do ambiente externo, as tendências de expansão e desaceleração do MAB no período 2004-2011 acompanharam também, em linhas gerais, o comportamento da economia brasileira. Essa coincidência reflete, em primeiro lugar, a natural influência mútua, já apontada, entre o mercado de ações e a atividade 
econômica em geral e, em segundo, o visível reforço desta relação a partir de 2004, como sugerem os índices das emissões primárias do MAB em relação à FBCF e ao PIB. Além disso, grande parte da correlação positiva entre o comportamento do PIB e do MAB nesse período deve ser atribuída ao fato de que, em economias liberalizadas, ambos são fortemente condicionados pelo mercado internacional. Diante da reversão do cenário externo favorável, que esteve na raiz da retomada do crescimento econômico e do MAB a partir de 2004, a desaceleração de ambos tornou-se inevitável.

Em suma, a análise aqui desenvolvida sugere que o perfil de risco da expansão recente contribuiu de forma importante, embora indireta, para a desaceleração do MAB a partir 2010 - ou de 2008, quando se leva em conta a concentração das emissões de 2008 e 2009 em poucas grandes empresas. Concretamente, a concentração da demanda nos segmentos primário e secundário em torno dos investidores estrangeiros "preparou" o MAB para o contágio diante de uma reversão do ambiente externo. Nessas condições, o recuo do mercado, a reboque de uma crise de confiança internacional, era absolutamente previsível, assim como o são novos rounds de desaceleração, enquanto se estender a crise internacional.

O que surpreende, na verdade, é a moderação do contágio, diante de um ambiente externo hostil e da desaceleração do crescimento econômico no Brasil. Apesar do comportamento um tanto errático do mercado nos anos 2008-2011, os volumes anuais de negócios do período estão longe de caracterizar um quadro de estagnação, sendo muito superiores, inclusive, às médias anuais do biênio 20042005 e pouco maiores que as dos anos 1995-1998, amplamente reconhecidos como fases de boa performance do MAB. Aparentemente, o contágio do MAB pela crise externa foi atenuado pelos fatores que contribuíram para a melhora dos indicadores de liquidez e volatilidade do mercado, entre eles:

a) o desempenho favorável da economia brasileira no período;

b) a redução dos riscos (de rendimento e de mercado) associada à maior adesão das empresas negociadas na Bovespa a critérios de governança corporativa, bem como o reforço das exigências neste sentido;

c) e a mudança da classificação de risco do país no mercado internacional, de "mercado especulativo" para "grau de investimento".

Por fim, quanto às perspectivas para o futuro próximo, o perfil de risco do MAB no período 2004-11 desenha um cenário pouco favorável à reversão da tendência de desaceleração dos últimos anos, considerando que:

a) os efeitos recessivos da crise externa sobre o mercado financeiro internacional e, em especial, sobre o crescimento econômico mundial ainda parecem longe de ser superados, tanto em seu país de origem (os EUA), quanto (e hoje, principalmente) na Zona do Euro; 
b) a economia brasileira já vem sendo também negativamente afetada por esse quadro. Ou seja, os dois principais fatores que impulsionaram o MAB no período 2004-08 atuam, a partir de 2009, no sentido oposto.

A superação desse perfil de risco e, portanto, da dinâmica de stop and go ditada pelo mercado internacional - típica de mercados acionários pouco desenvolvidos requer que se amplie a demanda doméstica por ações, especialmente no segmento primário do mercado. Para tanto, além de crescimento econômico continuado e, possivelmente, de políticas específicas para o mercado de ações, no caso brasileiro, certamente, são necessárias também políticas "externas" ao MAB. Face à conhecida "cultura de juros altos", que caracteriza o país, ininterruptamente, desde o início dos anos 1990, qualquer política de incentivo à expansão do MAB a partir da demanda doméstica deve contemplar medidas que visem reduzir, a níveis comparáveis aos praticados em mercados mais desenvolvidos, as vantagens comparativas dos títulos de renda fixa - e dos títulos públicos, em particular - sobre as ações. Desenvolver esta discussão, porém, ultrapassa os limites de nossos objetivos neste artigo, cabendo apenas menciona-la como complemento importante para futuras análises sobre o tema.

\section{Referências}

CARVALHO, F. J. C. Mr. Keynes and the Post-Keynesians. Cheltenham: Edward Elgar, 1992.

DAVIDSON, P. Money and the real world. London: MacMillan, 1978.

HERMANN, J. Liberalização e crises financeiras: o debate teórico e a experiências brasileira nos anos 1990. Tese (Doutorado em economia) - Instituto de Economia, Universidade Federal do Rio de Janeiro, Rio de Janeiro, 2002.

HERMANN, J. Liberalização financeira e crise cambial: a experiência brasileira no período 1987-99. In: SOBREIRA, R. (Org.). Regulação financeira e bancária. São Paulo: Atlas, 2005. p. $210-258$.

HERMANN, J. Liberalização e desenvolvimento financeiro: lições da experiência brasileira no período 1990-2006. Revista Economia e Sociedade, v. 19, n. 2, p. 257-290, ago. 2010.

HULL, J. Introdução aos mercados futuros e de opções. São Paulo: BMËF, 1998.

KEYNES, J. M. A teoria geral do emprego, do juro e da moeda. São Paulo: Abril Cultural, 1985.

KINDLEBERGER, C. P.; ALIBER, R. Z. Manias, panics, and crashes. $5^{\text {th }}$ ed. Hoboken: John Wiley and Sons, 2005.

PAULA, L. F. R. Financial Liberalization and Economic Performance: Brazil at the crossroads. London: Routledge, 2011.

PRATES, D. Investimentos de portfólio no mercado financeiro doméstico. In: FREITAS, M. C. P. (Org.). Abertura do sistema financeiro no Brasil nos anos 90. São Paulo: Brasília: FundapFapesp: IPEA, 1999. p.17-60. 
PRATES, D.; FREITAS, M. C. P. Emissões brasileiras no mercado financeiro internacional nos anos 90. In: FREITAS, M. C. P. (Org.). Abertura do sistema financeiro no Brasil nos anos 90. São Paulo: Brasília: Fundap-Fapesp: IPEA, 1999. p. 61-100.

UNIVERSIDADE ESTADUAL DE CAMPINAS - UNICAMP; Universidade Federal do Rio de Janeiro - UFRJ. Perspectivas da Indústria Financeira Brasileira e o Papel dos Bancos Públicos - Sub-Projeto: Mercado de Títulos Brasileiro. Segundo Relatório Parcial, Cap. II: Mercado de Ações Brasileiro: Análise das Causas e Condicionantes da Evolução Recente (2004-08). Projeto de Pesquisa BNDES-FECAMP. 2009. Disponível em: <www.iececon.net/pesquisa > Acesso em: 28 fev. 2012.

Recebido em: 10/03/2011.

Aceito em: 04/05/2012. 